\title{
Observational Study on the Initial Formation Process of the Mei-yu Frontal Disturbance in the Eastern Foot of the Tibetan Plateau in Middle-Late June 1992
}

\author{
Hideo TAKAHASHI \\ Department of Geography, Tokyo Gakugei University, Tokyo, Japan \\ (Manuscript received 27 August 1998, in revised form 27 June 2003)
}

\begin{abstract}
In this research, a case study is conducted on the formation process of the Mei-yu frontal disturbance in the eastern foot of the Tibetan Plateau. The target period is middle-late June of 1992, during which the Mei-yu front is re-intensified after the decaying phase observed in middle June.

The re-intensification process of the Mei-yu front occurs in accordance with the approach of the migrating upper level trough to the north of the Plateau. When the upper level trough is situated to the northwest or north of the Plateau, the lower level high pressure area becomes apparent. Subsequently, the low pressure area on the northeast of the Plateau deepens. At the same time, a shallow cold air mass observed below the $700 \mathrm{hPa}$ level formed in the southeast of the low pressure area. The appearance of the cold air mass might be related to the development of low and high pressure systems to the northnortheast of the Plateau.

Concurrently, a lower level strong westerly wind appears along the northern periphery of the Plateau, and turns into northwesterly or northerly wind along the eastern periphery of the Plateau. A shear line formed in the northeastern or eastern foot of the Plateau between this northwesterly wind and the southerly wind prevailing over the North-Middle China Plain. This shear line in the lower layer changed into the Mei-yu frontal disturbance after 00UTC 21 June. Note that the wind system along the northern-eastern periphery of the Plateau mentioned above is considered to be an ageostrophic wind system, accompanied by the transient small scale low and high pressure systems that migrate clockwise along the northern-eastern periphery of the Plateau.

The synchronic appearance of the cold air mass and the shear line is considered to be an effective trigger for the formation of the initial Mei-yu frontal disturbance. Further, the coupling of the upper level migrating trough and the lower level shear line also can be important for the evolution of the Meiyu frontal disturbance.
\end{abstract}

\section{Introduction}

The Mei-yu front over China (over Japan, it is termed the Baiu front) is considered to be a quasi-stationary subtropical front (Ninomiya 1984) that usually appears during the early summer rainy season. From the climatological

Corresponding author: Hideo Takahashi, Department of Geography, Tokyo Gakugei University, 41-1 Nukuikita Koganei Tokyo 184-8501, Japan.

E-mail: thideo@u-gakugei.ac.jp

(C) 2003, Meteorological Society of Japan point of view, the active duration of the Mei-yu front begins in the middle of June and ends in the middle of July (Ding 1992). During this period, the Mei-yu front locates in the area between $\sim 25^{\circ} \mathrm{N}$ and $\sim 35^{\circ} \mathrm{N}$ (Yoshino 1963) Though the appearance frequency of fronts in this period is much higher than that in other seasons, the cloud zone accompanied by the Mei-yu front does not necessarily appear in this area at all the time. The Mei-yu front indicates significant day-to-day variations, in other words, intensification and dissipation, or 
active and inactive phases of the Mei-yu front are evident. The lifetime of the heavy precipitation zone of the Mei-yu front defined as the time interval between the appearance of the precipitation area in the eastern part of the Tibetan Plateau and the dissipation of the precipitation zone over China is several days (Takahashi 1989). The activity of the Mei-yu front seems to be considerably affected by migrating middle or higher latitude synoptic systems, even though the water vapor supply is controlled mainly by the lower latitude circulation system as a subtropical anticyclone (Kato 1989; Kato and Kurihara 1989) and the lowlevel jet stream in the case of heavy precipitation (Akiyama 1973, 1975). Further, Chen (1994) pointed out that the southward shift of the northern baroclinic zone is one of the favorable conditions for the active Mei-yu over South China and Taiwan.

Takahashi (1989) also pointed out that the precipitation zone during the Mei-yu season over China tends to be intensified in the presence of the lower level (below 850 or $700 \mathrm{hPa}$ level) cold air mass of meso- $\alpha$-scale to the east of the Plateau. The lower level cold air mass can lift the warm and moist air mass to release convective instability, and create a trigger effect for the formation of disturbances to the east of the Tibetan Plateau (Takahashi 1989). Furthermore, it was suggested that the eastward migration of the middle latitude trough to the north of the Plateau also is related to the appearance of the cold air mass (Takahashi 1991). However, the appearance process of the cold air mass and the related wind system around the Plateau were not clarified in Takahashi $(1989,1991)$ due to the limitation of invested data over China.

According to the composite analysis of temperature and wind field during the 1979 summer (Murakami and Huang 1984), the heavy rainfall over the Yangtze River basin before the onset of the Mei-yu season is caused by the disturbance that appeared in the northeastern edge of the Plateau under the relatively large meridional temperature gradient. On the other hand, heavy rainfall after the onset of the Meiyu season over the Yangtze River basin occurs due to the disturbance generated in the western part of the Plateau. Akiyama (1990a) indicates that the upper level disturbance migrat- ing from Central Asia along the upper level jet stream contributes to the development of medium scale disturbance in the east coast of the continent. Further, Akiyama (1990b) and Ninomiya and Akiyama (1992) discussed the relationship between the multi-scale feature of disturbances and the structure of the Mei-yu front based on the spectrum analysis of the relative vorticity field and cloud data. Ding et al. (2001) pointed out that the migrating disturbance of the meso-scale originating in the eastern flank of the Plateau occurred several times during the Mei-yu seasons of both 1998 and 1999, and produced heavy precipitation to the southeast of the disturbance. However, the detailed process of the synoptic or meso-scale system that contributed to the formation of the disturbance around the Plateau has not been analyzed fully. To resolve complicated phenomena, such as the formation process of the Mei-yu frontal disturbance, case analysis should be one of the effective methods. The present study aims to document the initial formation process of the Mei-yu frontal disturbance in the eastern foot of the Plateau by means of case analysis of the temporal change in the synoptic field of middle and higher latitudes.

In this paper, the target case is selected from the Mei-yu season of 1992. According to Liu (1992), the total precipitation amount in June of 1992 was almost normal around and to the south of the Yangtze River basin, although the Yellow River basin was rather dry. In July, the northward migration of the precipitation zone was distinct, and hence the drought in the Yellow River basin was eased (Tang 1992). Accordingly, the Mei-yu season of 1992 is considered to be a near normal one, and thus the target case is expected to indicate the general features of the formation process of the Mei-yu frontal disturbance.

\section{Data and outline of analysis procedure}

In this study, upper air observation data at standard pressure levels in the area of $30^{\circ} \mathrm{E}-$ $180^{\circ}$ and $0-90^{\circ} \mathrm{N}$, which are extracted from the SD data compiled by the Japan Meteorological Agency (JMA), are utilized. Figure 1 shows the distribution of the upper air stations recorded in the SD data. Although the original SD data contains more than 460 stations, the data at 


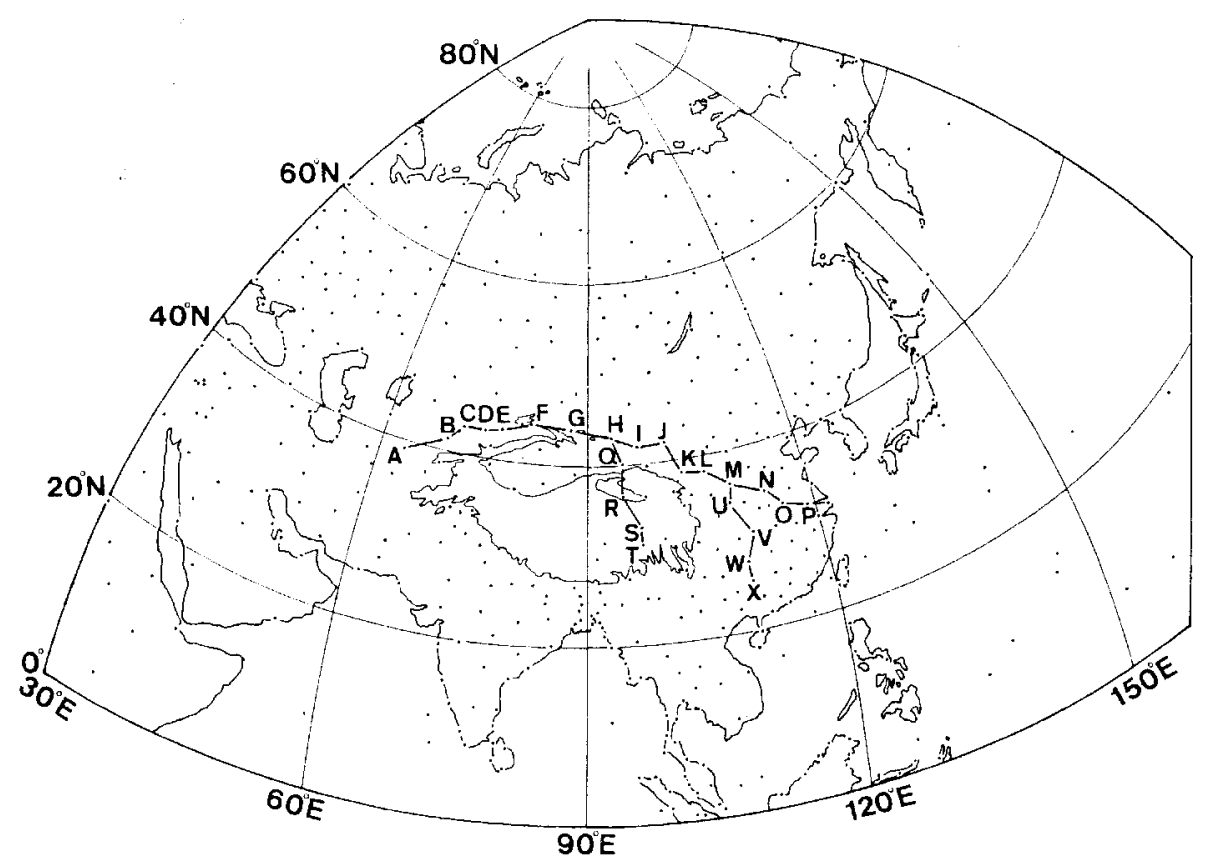

Fig. 1. Distribution of upper air stations (dots) utilized in this study. A longitudinal section to the north of the Tibetan Plateau (A-P), and two meridional sections on $(\mathrm{H}, \mathrm{Q}-\mathrm{T})$ and to the east $(\mathrm{M}$, $\mathrm{U}-\mathrm{X})$ of the Plateau are also indicated.

about 350 stations are used for the daily analysis due to missing data at the other stations. Analysis on the air temperature distribution is mainly performed at the $850 \mathrm{hPa}$ level to detect the low temperature area that appears in the lower level to the east of the Plateau. The longitudinal vertical section to the north of the Plateau (stations A-P), and two meridional vertical sections on (stations $\mathrm{H}, \mathrm{Q}-\mathrm{T}$ ) and to the east (stations $\mathrm{M}, \mathrm{U}-\mathrm{X}$ ) of the Plateau (Fig:1) up to the $200 \mathrm{hPa}$ level are also investigated to clarify the vertical structure of the temperature and wind distribution around the Plateau.

Further, the global objective analysis data (G-ANAL) compiled by the JMA with the spatial resolution of $1.875^{\circ} \times 1.875^{\circ}$ is utilized for calculating relative vorticity and the analysis on the formation of shear line in chapter 6 . In addition, the daily weather charts published by the JMA and the GMS IR cloud images also are employed to detect the location of the Mei-yu front and the large scale features around the Plateau.

\section{Overview of the target case}

Figure 2 shows the location of surface fronts along the $112^{\circ} \mathrm{E}$ meridional line at every 12UTC from April to September of 1992. Fronts

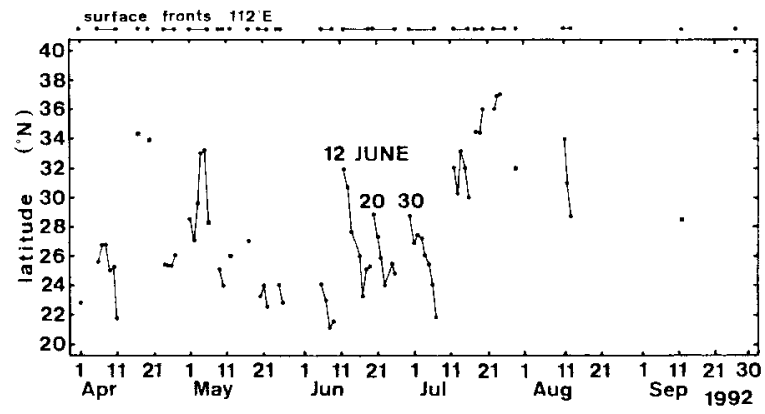

Fig. 2. Appearance latitude of fronts along $112^{\circ} \mathrm{E}$ meridional line on the surface weather charts from April to September of 1992. Periods when fronts appear consecutively are shown on the top of the panel with indicating the first and last date by dots. 
appear in $25-35^{\circ} \mathrm{N}$ almost continuously from 12 June to 25 July. This period is considered to be the Mei-yu season over the Yangtze River basin in 1992. Furthermore, the Mei-yu season of 1992 can be divided into two periods in terms of the day-to-day displacement of the Mei-yu front. In the former half of the Mei-yu season (from 12 June to 7 July), a series of "emergence of front around $30^{\circ} \mathrm{N}$, its successive southward migration, and dissipation of the front around $25^{\circ} \mathrm{N}$ " is repeated three times. Such typical cycles of the intense-decay phase of the Mei-yu front are seen also on the surface weather charts in this period. On the contrary, in the latter half of the Mei-yu season (from 12 to 25 July), the Mei-yu front migrates northward gradually. Thus, the middle to late June of 1992 was selected as the target period in the present analysis.

During the target period, a low temperature area to the east of the Plateau is detected at the $850 \mathrm{hPa}$ level in all three cases at the intensification stage of the front (around 12, 20 and 30 June). Of these cases, the intensification stage of the Mei-yu front around 20 June is analyzed in this study.

Figure 3 shows the surface weather charts at 12UTC 19 (Fig. 3a) and 20 (Fig. 3b) June. Though the Mei-yu front over China is not recognized on the weather chart at 12UTC of 19 June (a), it is detected around $30^{\circ} \mathrm{N}$ to the east of the Plateau at 12UTC 20 June (b). According to the GMS IR cloud image at 12UTC on 20 June (Fig. 17-upper), active clouds begin to organize around the Mei-yu front. In Fig. 3, the approximate location of the low temperature area $\left(\leqq 12^{\circ} \mathrm{C}\right)$ that appeared to the east of the Plateau at the $850 \mathrm{hPa}$ level is indicated by a shaded area, which is duplicated from Fig. 11 and Fig. 4 for Fig. 3a and Fig. 3b, respectively. The low temperature area expanded southeastward from 19 to 20 June, and the re-intensified surface Mei-yu front at 12UTC 20 June is located to the south of the low temperature area.

The distribution of temperature and geopotential height at the $850 \mathrm{hPa}$ level for 12UTC 20 June is shown in Fig. 4. Heavy (light) shade indicates the area of negative temperature anomaly below $-8^{\circ} \mathrm{C}\left(-4^{\circ} \mathrm{C}\right)$ from the 10-day average temperature field from 13 to 22 June for 12UTC. Note that the analyses shown in Figs. 4-15 are based on the original upper air a)

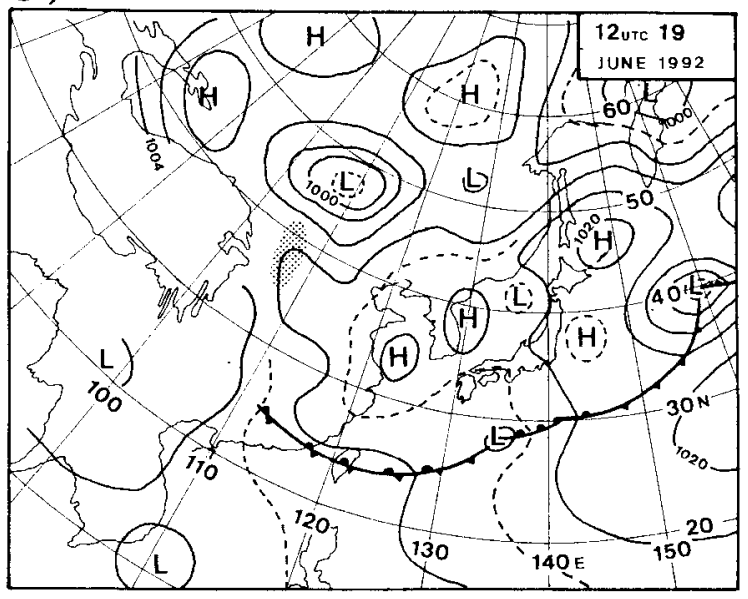

b)

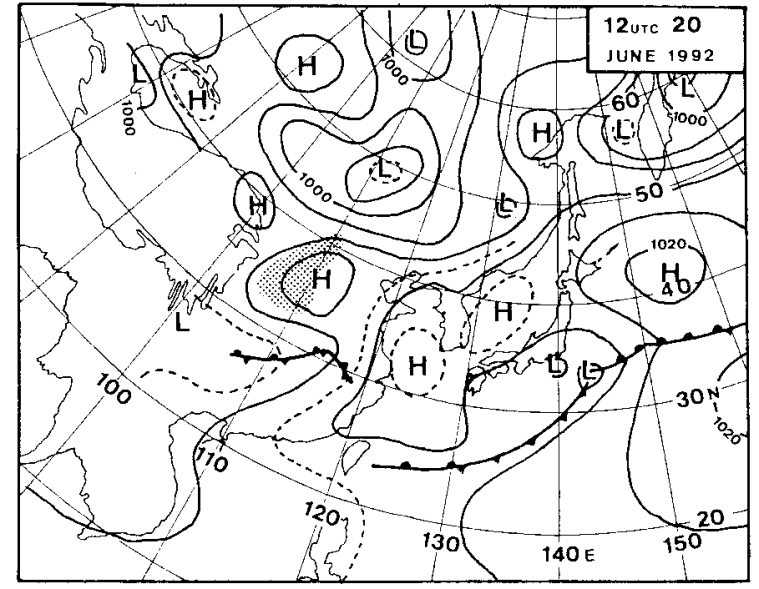

Fig. 3. Surface weather charts for 12UTC 19 (a) and 20 (b) June. Shaded area indicates approximate location of the low temperature area $\left(\leqq 12^{\circ} \mathrm{C}\right)$ appeared to the east of the Plateau at the $850 \mathrm{hPa}$ level.

observation data. At 12UTC 20 June, the low temperature area of meso- $\alpha$-scale, which corresponds to the area with large negative temperature anomaly, is clearly observed to the east of the Plateau. Observed temperature at the center of this cold area is about $10^{\circ} \mathrm{C}$ and is lower than that over the South China Plain by about $10^{\circ} \mathrm{C}$. Therefore, a zone of relatively large meridional temperature gradient appears to the south of the low temperature area. Moreover, a meso-scale low on the Mei-yu front is embedded in the large temperature gradient 


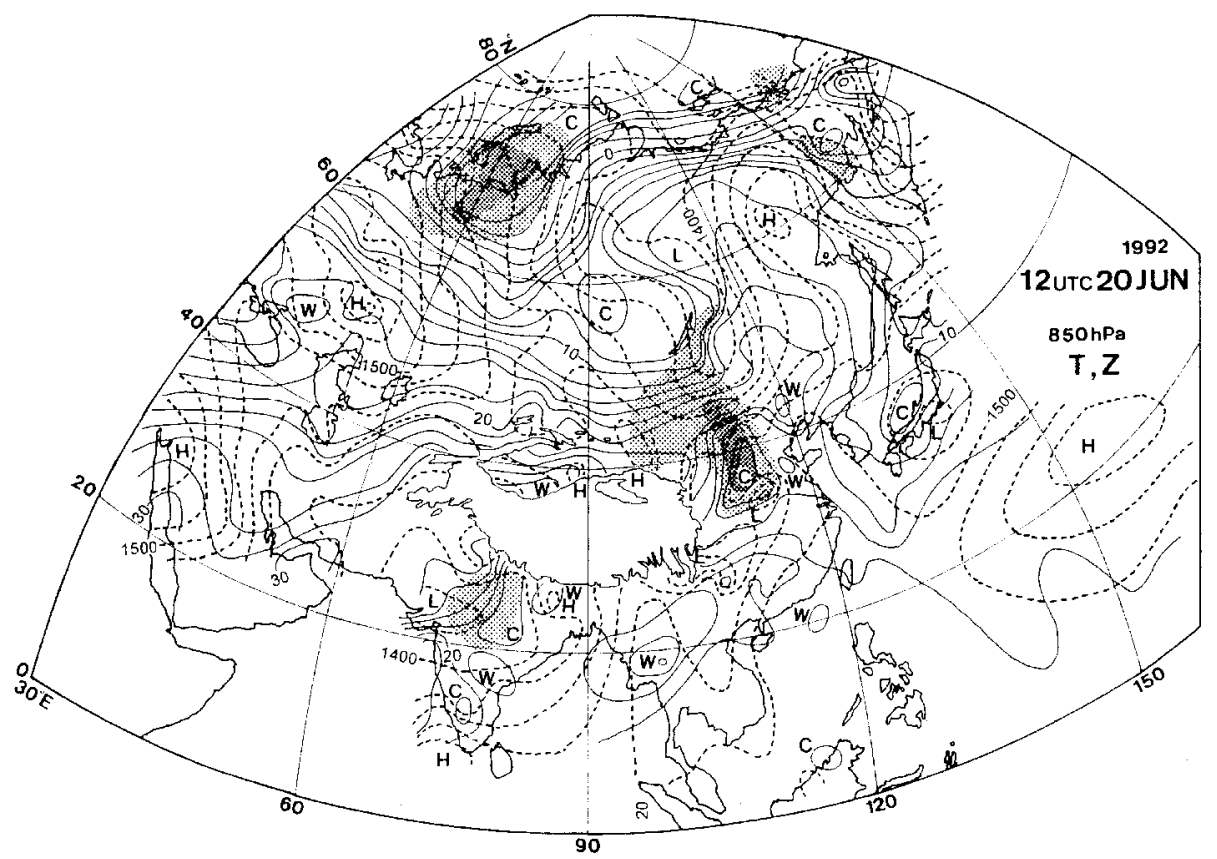

Fig. 4. Distribution of temperature (solid line) and geopotential height (broken line) at the $850 \mathrm{hPa}$ level at 12UTC 20 June when the re-intensified Mei-yu front appears around $30^{\circ} \mathrm{N}$ of $107-119^{\circ} \mathrm{E}$. Contour lines of temperature and geopotential height are drawn at the interval of $2^{\circ} \mathrm{C}$ and $20 \mathrm{gpm}$, respectively. Heavy (light) shade indicates the area with negative temperature anomaly below $-8^{\circ} \mathrm{C}\left(-4^{\circ} \mathrm{C}\right)$ from the 10-day average temperature field from 13 to 22 June for $12 \mathrm{UTC}$.

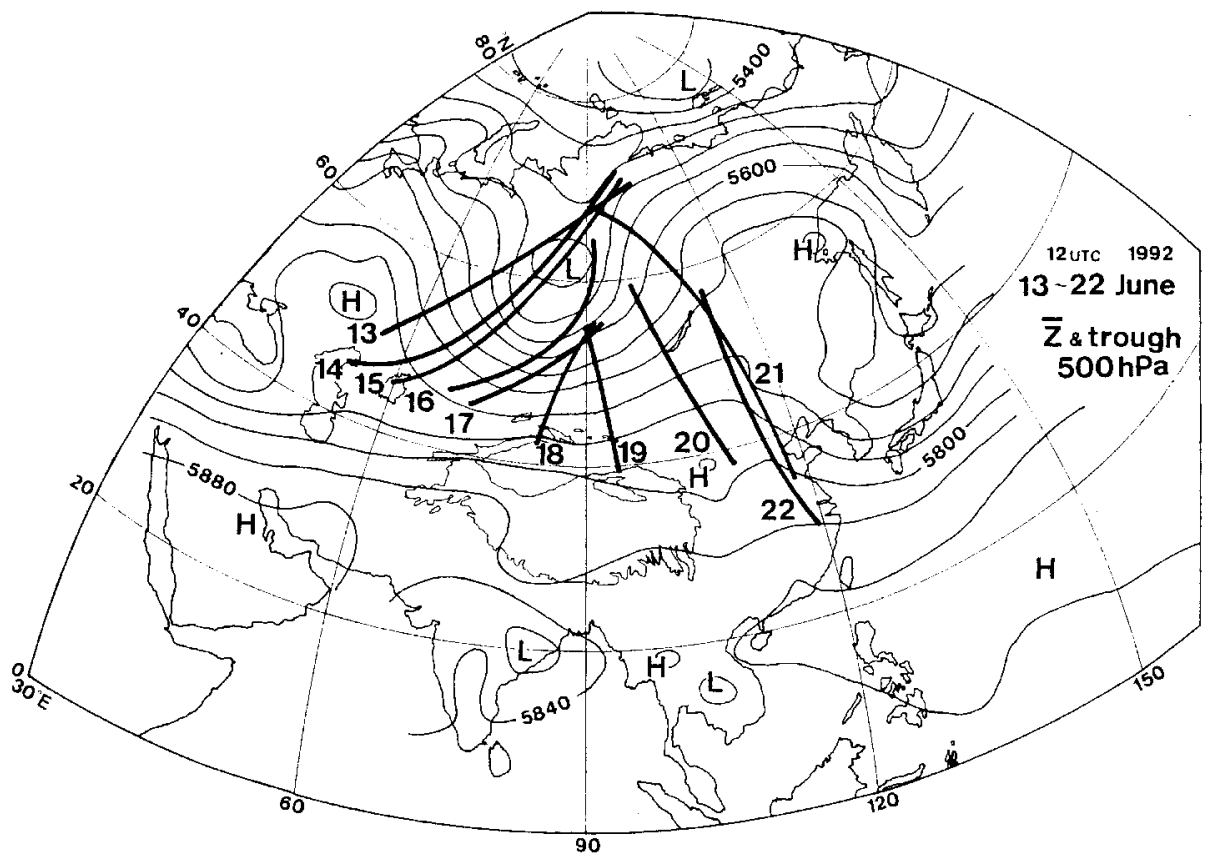

Fig. 5. Average $500 \mathrm{hPa}$ level height and the location of migrating trough at the $500 \mathrm{hPa}$ level from 13 to 22 June of 1992 . Contour lines are drawn at every $40 \mathrm{gpm}$. As for the location of the trough (thick solid line), refer to the text in chapter 3. 


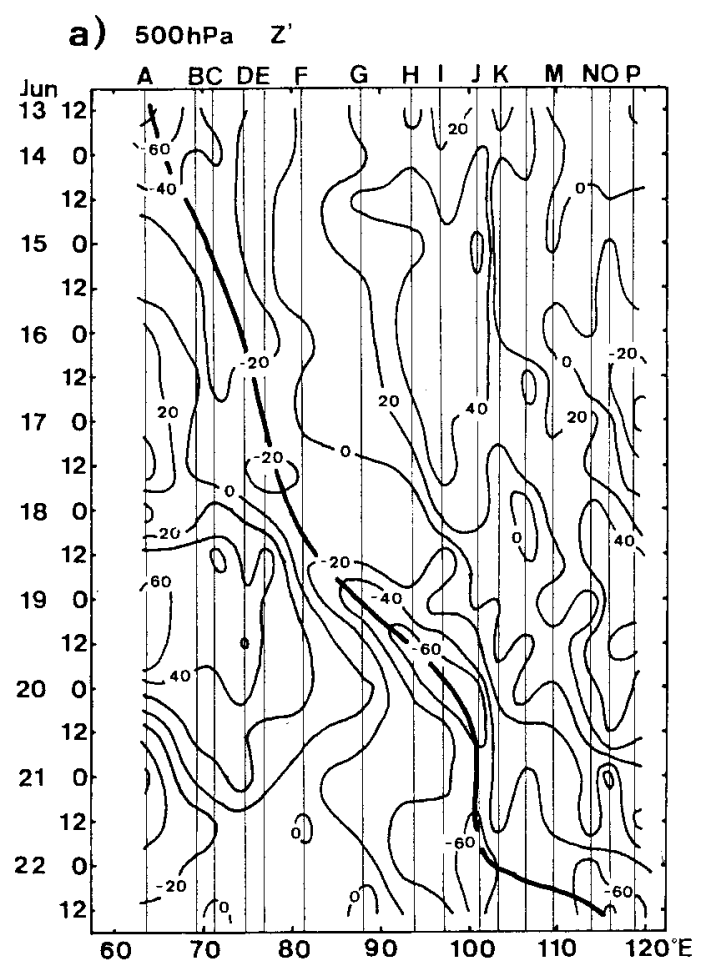

b) $850 \mathrm{hPa} \mathrm{Z}^{\prime}$

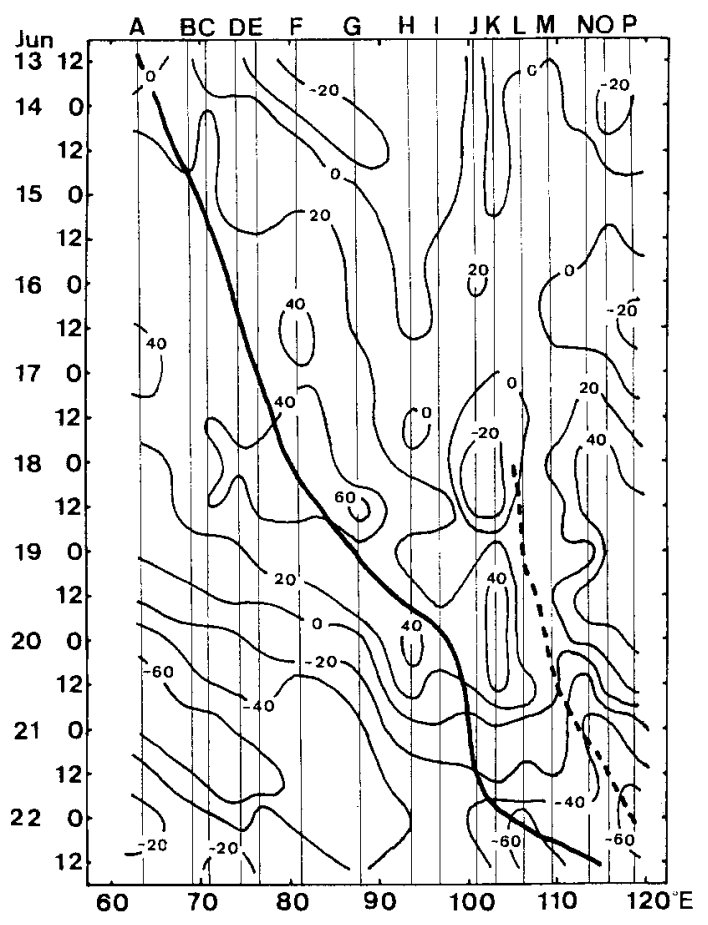

C) $850 \mathrm{hPa} \mathrm{T}^{\prime}$

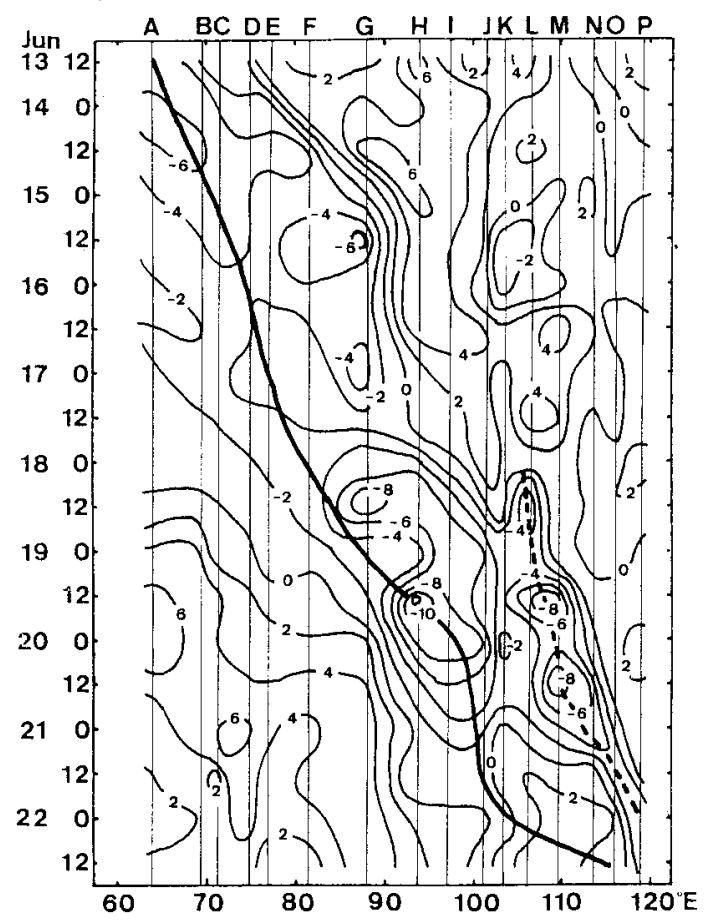

Fig. 6. Day-to-day change in the $500 \mathrm{hPa}$ (a) and $850 \mathrm{hPa}$ (b) level height anomaly (gpm), and $850 \mathrm{hPa}$ level temperature anomaly $\left({ }^{\circ} \mathrm{C}\right)$ (c) along the longitudinal section to the north of the Tibetan Plateau (A-P). Thick solid line in each panel indicates the location of the migrating trough (axis of negative anomaly of the $500 \mathrm{hPa}$ level height) in Fig. 6a. Thick broken line in Figs. 6b and $6 \mathrm{c}$ shows the migrating path of the low temperature area that appeared to the east of the Plateau at 00-12UTC 18 June (Fig. 6c). 
zone just to the southeast of the low temperature area.

Figure 5 shows a 10-day average $500 \mathrm{hPa}$ height field from 13 to 22 June. The location of the trough lines at 12UTC (thick solid line) also are presented in Fig. 5. The location of trough lines on the respective days has been defined as the axis of a large negative anomaly of the daily $500 \mathrm{hPa}$ geopotential height from the 10day average field between 13 and 22 June. At 12UTC 20 June, the $500 \mathrm{hPa}$ level trough is situated to the northwest of the low temperature area. This short wave trough migrates along the periphery of the quasi-stationary blocking trough located around $60^{\circ} \mathrm{N}$ of $90^{\circ} \mathrm{E}$, shown in Fig. 5.

Figure 6 shows the time-longitude cross sections of height anomaly at the $500 \mathrm{hPa}$ level (a), and that of height (b) and temperature (c) anomaly at the $850 \mathrm{hPa}$ level from respective 10-day average fields (from 13 to 22 June) along the east-west section to the north of the Plateau (stations A-P in Fig. 1). Anomalies for 00UTC and 12UTC have been calculated separately from respective 10-day average fields to eliminate the diurnal variation. As shown in Fig. 5, the $500 \mathrm{hPa}$ level trough, which is defined by the axis of negative height anomaly, migrates eastward with the phase velocity of 4-5 degree day ${ }^{-1}$ during this period (thick solid line in Fig. 6). On the contrary, at the $850 \mathrm{hPa}$ level (Fig. 6b), positive height anomaly is observed along the migration path of the $500 \mathrm{hPa}$ level trough. Namely, the lower level high pressure area appears under the upper level trough, which means that this short wave trough indicates baroclinic structure. The positive height anomaly becomes rather marked between $70^{\circ} \mathrm{E}$ and $105^{\circ} \mathrm{E}$ on the days between 17 to 20 June.

According to the day-to-day change in the $850 \mathrm{hPa}$ level temperature (Fig. 6c), the area of negative temperature anomaly migrates eastward along with the $500 \mathrm{hPa}$ level trough. However, it must be noted that another low temperature area appears to the east of the trough $\left(\sim 105^{\circ} \mathrm{E}\right)$ after 00UTC 18 June, and it migrates eastward slowly (thick broken line in Figs. 6b,c). This low temperature area corresponds to the meso- $\alpha$-scale cold air mass observed to the east of the Plateau in Fig. 4. At the initial time of the appearance of this low temperature area in $105-110^{\circ} \mathrm{E}(00-12 \mathrm{UTC}$ 18 June), a negative height anomaly at the $850 \mathrm{hPa}$ level (Fig. 6b) is observed to the west of the low temperature area in $100-105^{\circ} \mathrm{E}$.

In the next chapter, day-to-day change in the $850 \mathrm{hPa}$ level temperature and geopotential height will be documented to describe the atmospheric process during the passage of the upper level trough to the north of the Plateau.

\section{Day-to-day changes in the lower level temperature and height field during the passage of the upper level trough}

Figure 7 shows the distribution of temperature and geopotential height at the $850 \mathrm{hPa}$ level at 12UTC 13 June, seven days before the appearance of the front to the east of the Plateau. The center of the low temperature area that corresponds to the trough (Fig. 5) is located around $60-70^{\circ} \mathrm{N}$ of $80-90^{\circ} \mathrm{E}$ to the northwest of the Plateau at this time. The temperature gradient is large in the southern and eastern periphery $\left(50-70^{\circ} \mathrm{N}\right)$ of the low temperature area. This baroclinic zone corresponds to the Eurasian polar frontal zone (Yoshimura 1967; Yoshino 1969; Matsumoto 1985). At this time, another low temperature area is observed to the east of the Plateau, which contributes to the re-intensification of the Mei-yu front on 12 June (Fig. 2).

Afterwards, the upper level trough migrates southeastward slowly, and it approaches the northwestern side of the Plateau at 12UTC 16 June (Fig. 8). The forefront of the low temperature area accompanied by the upper level trough also displaces southward. The large temperature gradient zone exceeding $10^{\circ} \mathrm{C} / 500 \mathrm{~km}$ is located $\sim 40^{\circ} \mathrm{N}$ of $70-100^{\circ} \mathrm{E}$, which comprises a boundary between the continental polar air mass accompanied by the upper level trough and the high temperature area over the arid or semi-arid region on the north side of the Plateau. A high pressure zone with an east-west oriented ridge from the Aral Sea begins to appear on the north side of the Tian-Shan mountain range at this time. As a thermal low pressure is situated on the north of the Plateau, the gradient of height field to the north of the Plateau indicates north-south direction.

Twenty-four hours later (12UTC 17 June), the east edge of the high pressure zone under the upper level trough reaches the east of Tian- 


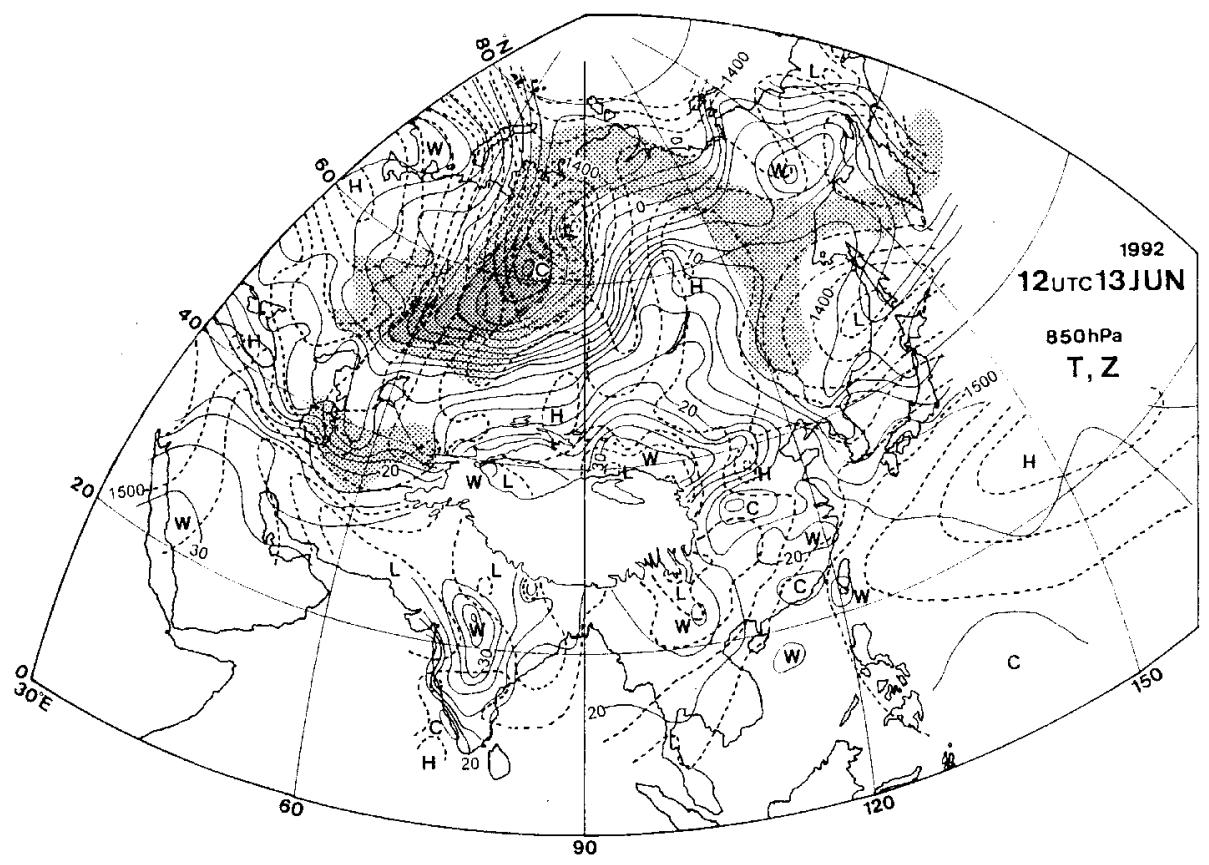

Fig. 7. Same as Fig. 4, but for 12UTC 13 June.

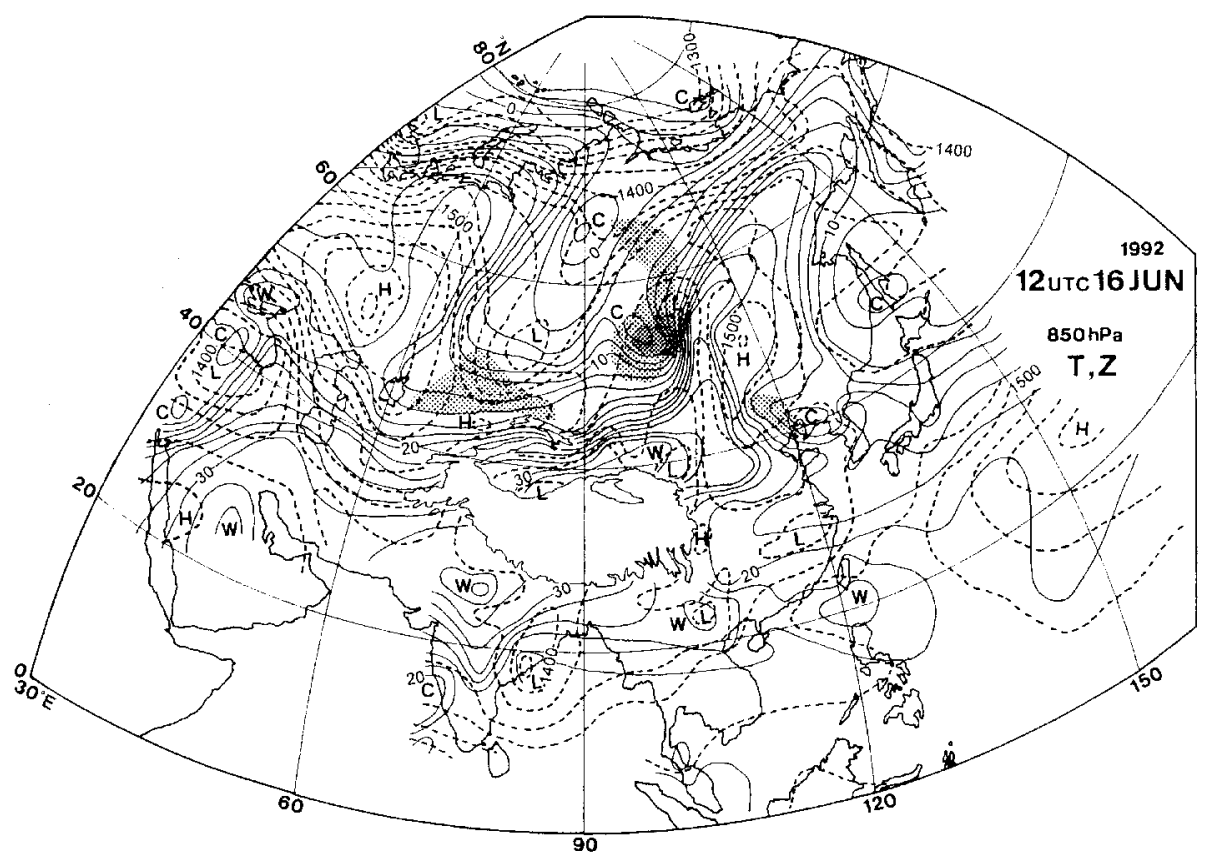

Fig. 8. Same as Fig. 4, but for 12UTC 16 June.

Shan mountain range (Fig. 9). On the north side of the Plateau $\left(\sim 40^{\circ} \mathrm{N}\right.$ of $\left.\sim 87^{\circ} \mathrm{E}\right)$, where the eastern tip of the high pressure area in- dicated by the contour line of $1480 \mathrm{gpm}$ or $1460 \mathrm{gpm}$ arrives, temperature falls approximately $10^{\circ} \mathrm{C}$ during the preceding 24 hours, 


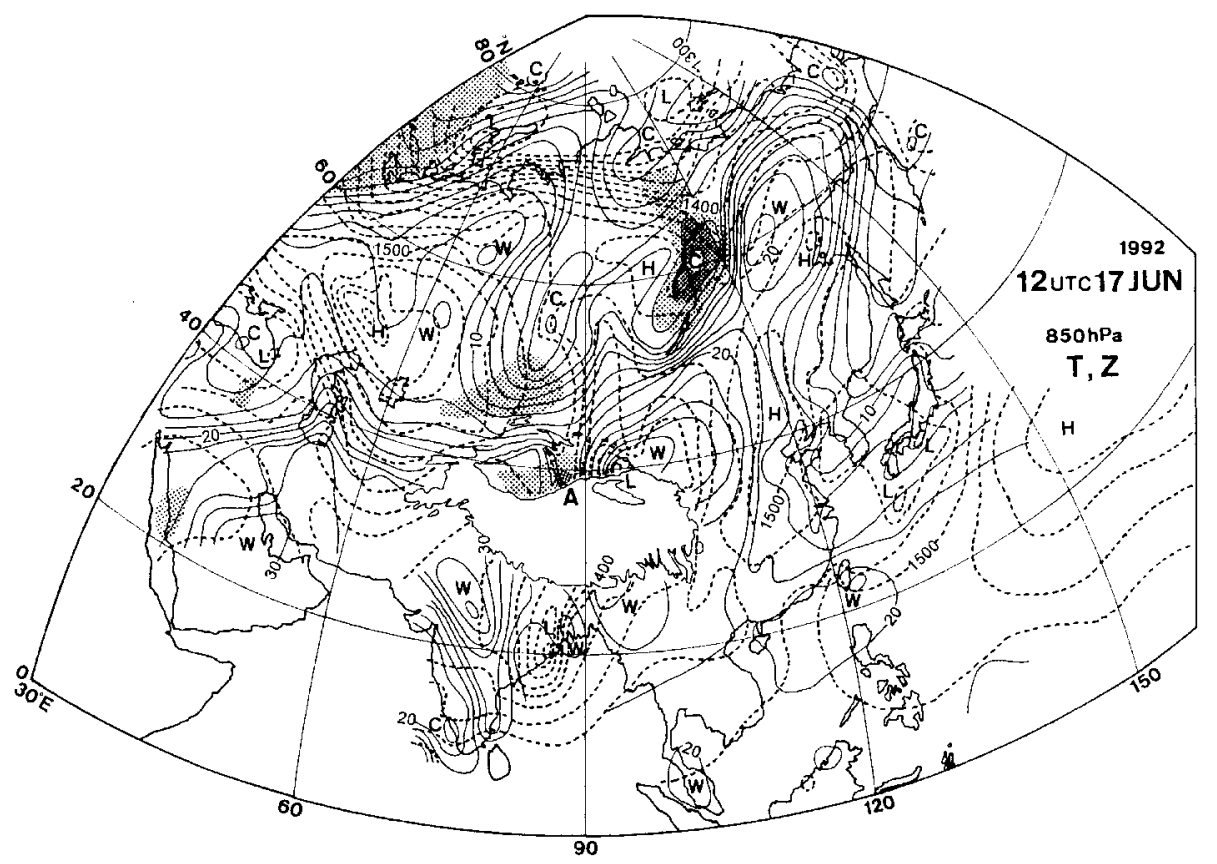

Fig. 9. Same as Fig. 4, but for 12UTC 17 June. "A" denotes the area of negative temperature anomaly appeared to the north of the Plateau (LTA-A).

and, consequently, a center of negative anomaly area of temperature appears there. Hereafter, this low temperature area (negative anomaly area) is referred to as LTA-A ("A" in Figs. 9-11). As the LTA-A intrudes into the high temperature area on the north of the Plateau, the high temperature area is divided into eastern and western parts. The direction of the gradient of the height field to the north of the Plateau changes from north-south direction into east-west direction, since the high pressure area occupies the western half of the north side of the Plateau and the low pressure area to the northeast of the Plateau begins to deepen.

When the upper level trough reaches the northern side of the Tian-Shan mountain range at 12UTC 18 June (Fig. 10), the high pressure area under the upper level trough and the low pressure system located to the northeast of the Plateau become both conspicuous. In other words, the pressure gradient becomes large to the north and northeast of the Plateau. The LTA-A that can be pursued from the previous day is located in the southeast side of the high pressure area under the upper level trough. By contrast, the temperature begins to fall in the area between the high pressure area over the North China Plain and the low pressure area to the northeast of the Plateau, and thus another low temperature area appears there. Hereafter, this low temperature area is referred to as LTA-B ("B" in Figs. 10 and 11). The appearance of the LTA-B might be related to the enhancement of pressure gradient to the northnortheast of the Plateau, though the physical process must be investigated further.

The LTA-B to the northeast of the Plateau becomes distinct abruptly at 12UTC 19 June (Fig. 11). The LTA-B migrates eastward along with the LTA-A located on the north of the Plateau. After the passage of the upper level trough to the north of the Plateau, the LTA-A becomes less distinct at 12UTC 19 June (Fig. $4)$.

\section{Vertical structure of the low temperature area}

\subsection{Temperature field}

In this chapter, analysis will be extended to the vertical structure of two negative anomaly areas of temperature that appeared to the north (LTA-A) and northeast (LTA-B) of the 


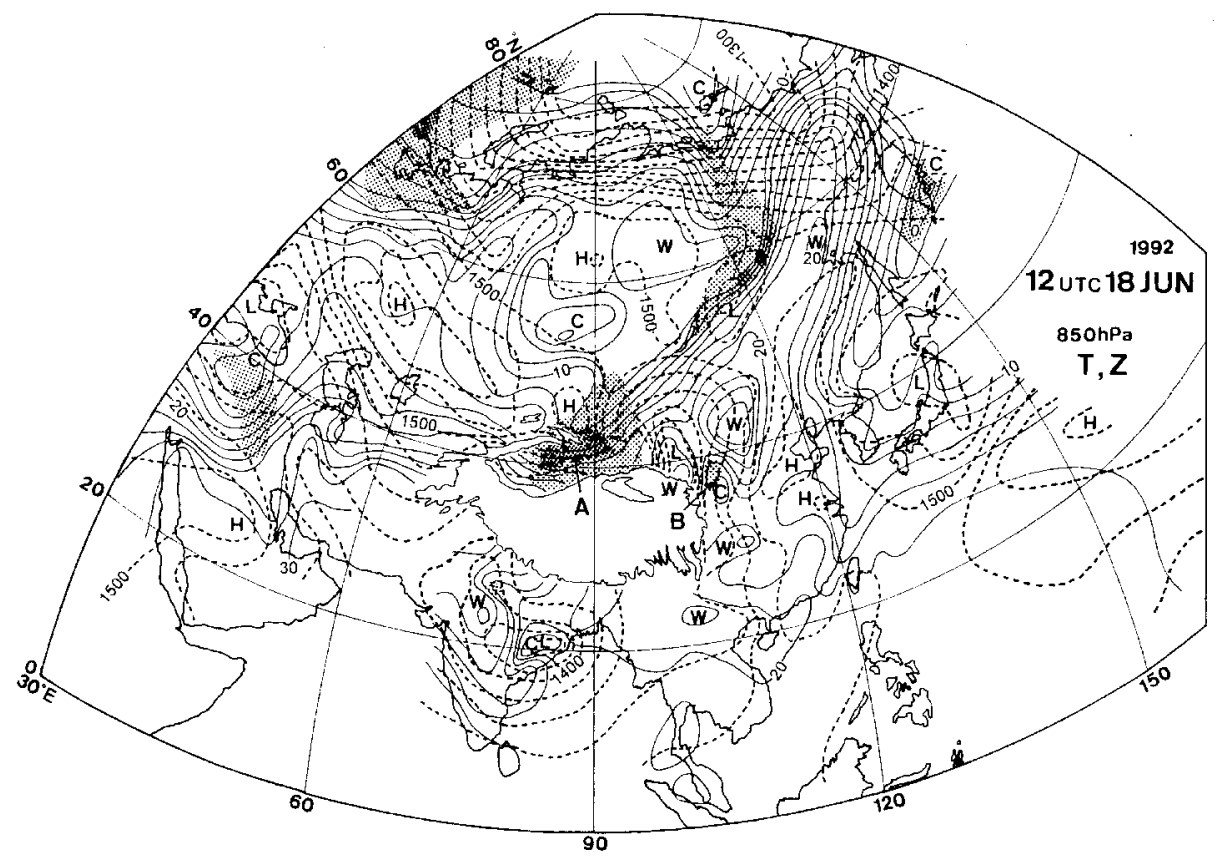

Fig. 10. Same as Fig. 4, but for 12UTC 18 June. "A" and "B" denote the areas of negative temperature anomaly appeared to the north (LTA-A) and northeast (LTA-B) of the Plateau, respectively.

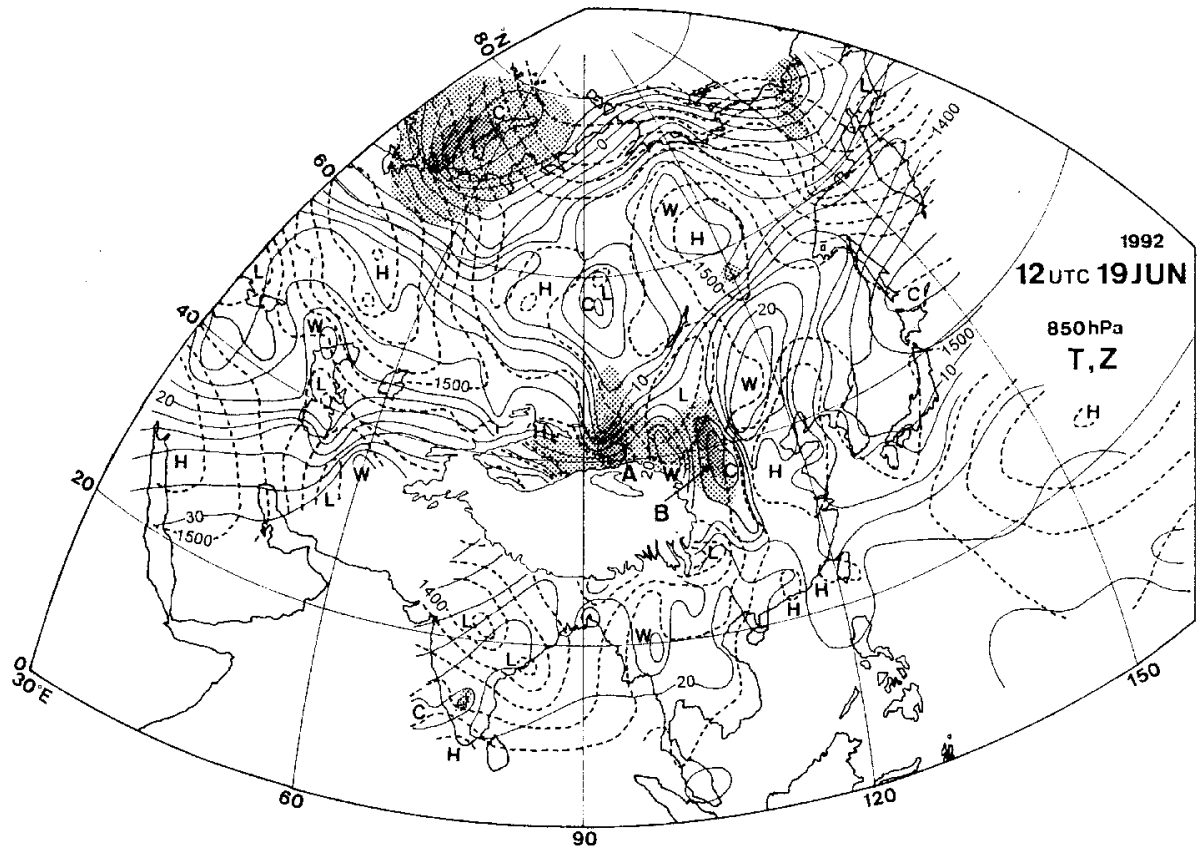

Fig. 11. Same as Fig. 4, but for 12UTC 19 June. As for "A" and "B", refer to the legend of Fig. 10. 

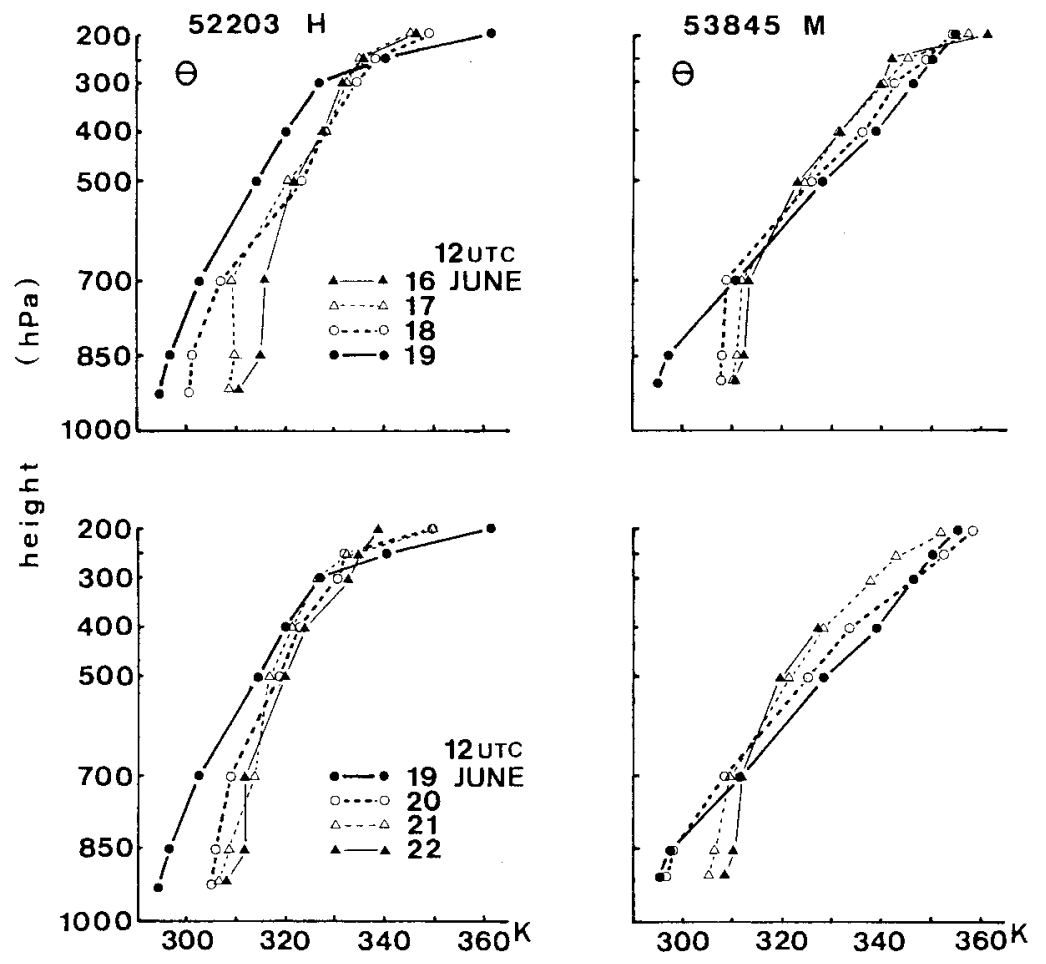

Fig. 12. Potential temperature profiles at station H (52203; left) and M (53845; right) from 16 to 19 (upper) and from 19 to 22 (lower) of June for 12UTC. Stations H and M correspond to the centers of large negative temperature anomaly appeared to the north (LTA-A) and northeast (LTA-B) of the Tibetan Plateau in Fig. 11, respectively.

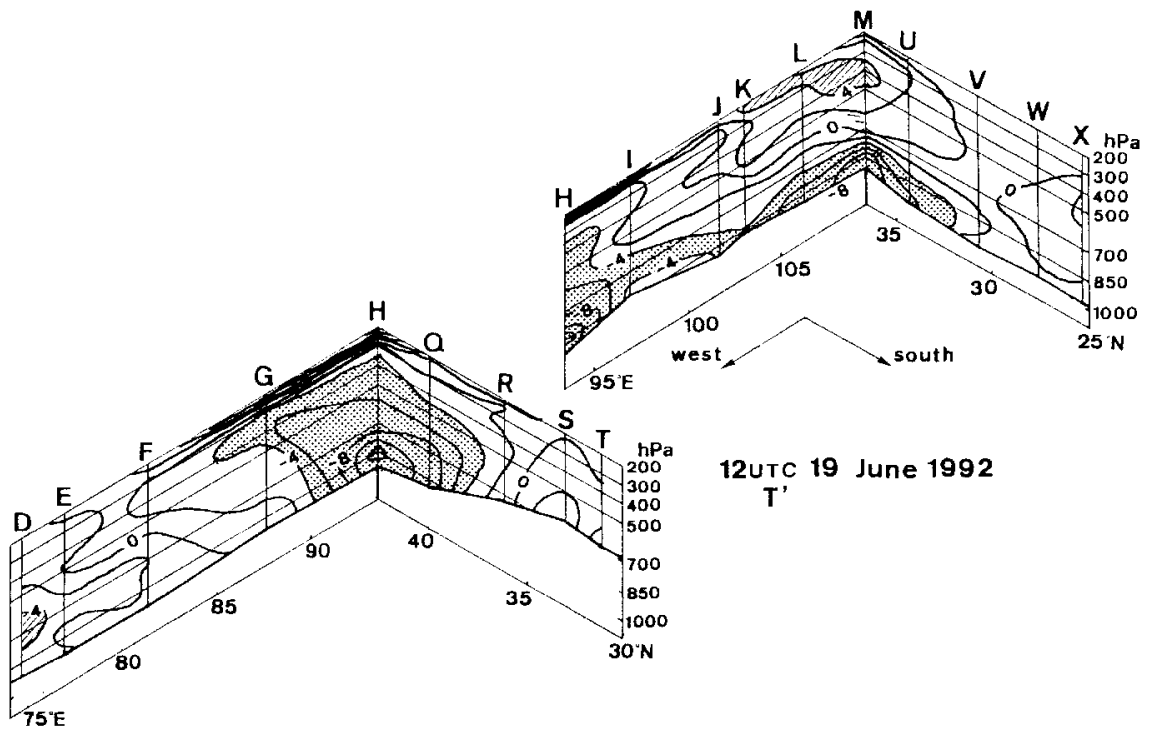

Fig. 13. Vertical structure of temperature anomaly distribution around the Tibetan Plateau for 12UTC 19 June. Shaded (hatched) area shows the negative (positive) anomaly larger than $4^{\circ} \mathrm{C}$ from the 10-day average field between 13 and 22 of June. 

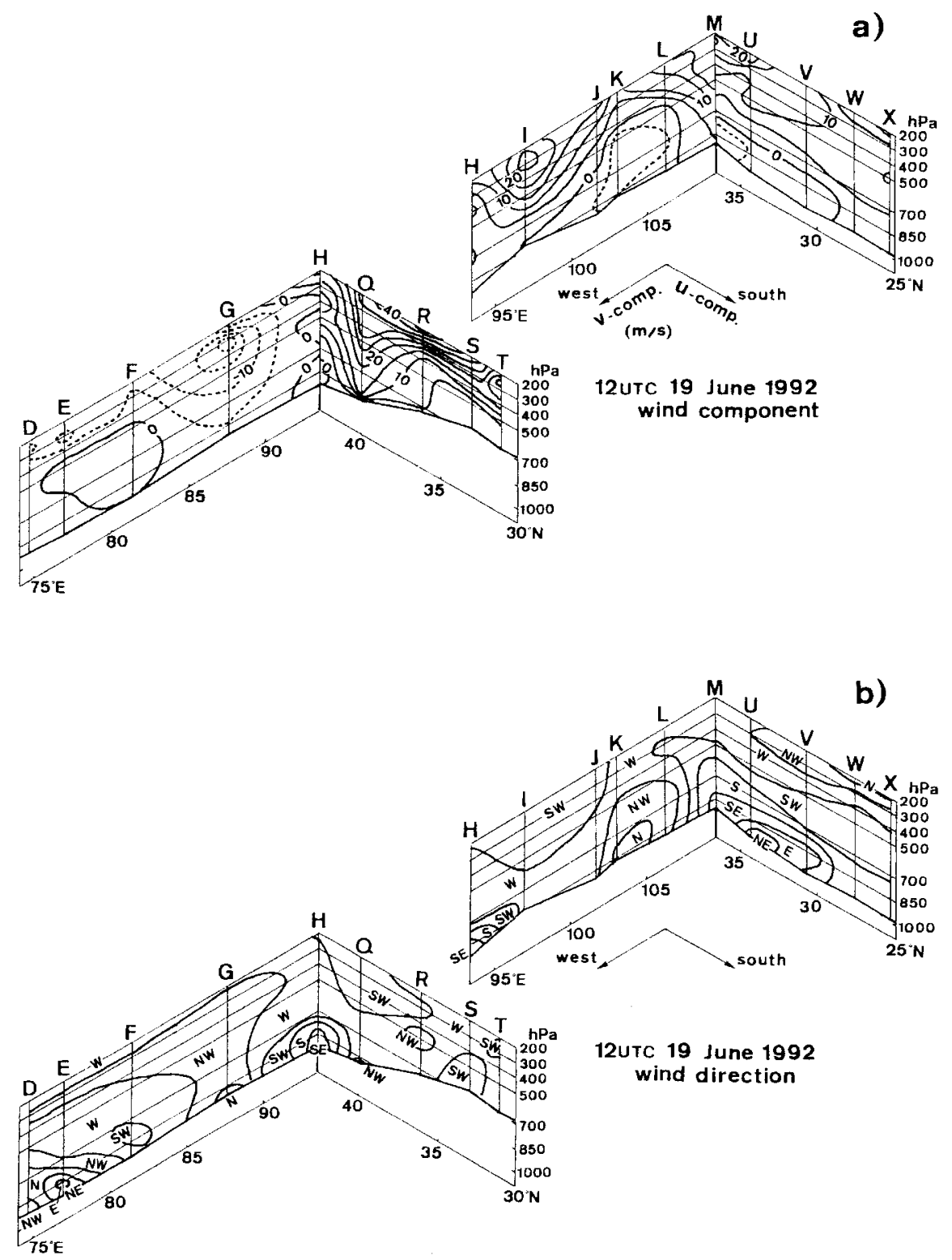

Fig. 14. Vertical structure of wind field around the Tibetan Plateau for 12UTC 19 June.

a) wind velocity component $\left(\mathrm{m} \mathrm{s}^{-1}\right)$ : meridional wind component in the longitudinal section and zonal wind component in the meridional sections are demonstrated in the figure.

b) wind direction (in eight directions).

Plateau. At first, the vertical profiles of potential temperature at the center of the respective negative anomalies of temperature are compared. The day-to-day changes in potential temperature profiles at 12UTC for stations $\mathrm{H}$ and M (see Fig. 1), the core of two negative anomaly areas of temperature on 19 June (Fig. 11), are shown in Fig. 12. For both stations, upper and lower panels in Fig. 12 show the potential temperature profiles from 16 to 19 June and from 19 to 22 June, respectively. According to Fig. 12, a decrease in potential temperature at station $\mathrm{M}$ (corresponding to LTA-B) occurs in the lower layer below the $700 \mathrm{hPa}$ level, though the temperature above the $500 \mathrm{hPa}$ level rises slightly. By contrast, at station $\mathrm{H}$ 
(corresponding to LTA-A), potential temperature decreases almost the entire troposphere below the $300 \mathrm{hPa}$ level until 18 or 19 June. After 19 June, potential temperature at station $\mathrm{H}$ rises in almost all levels. As for station $M$, it is restricted to the lower troposphere below the $700 \mathrm{hPa}$ level, where potential temperature rises after 19 June. Above the $700 \mathrm{hPa}$ level, potential temperature slightly falls down after 19 June at station M. Although the structure of the LTA-A in the north of the Plateau is deep, the LTA-B that appears to the northeast of the Plateau is a shallow one. The low temperature area with deep structure is not recognized to the east of the Plateau after 20 June when the upper level trough has passed through the north of the Plateau.

Figure 13 shows the temperature anomaly profiles of the longitudinal and meridional section (see Fig. 1) at 12UTC 19 June viewed from the southwest of the Plateau. Shaded and hatched areas indicate negative and positive anomaly more than $4^{\circ} \mathrm{C}$, respectively, from the 10-day average field between 13 and 22 June. The negative temperature anomaly corresponding to the LTA-A around $90-95^{\circ} \mathrm{E}$ inclines westward with height that indicates the baroclinic wave structure of this system. In addition, the negative temperature anomaly of LTA-A does not reach the central part of the Plateau. By contrast, the negative temperature anomaly of LTA-B located around $105-110^{\circ} \mathrm{E}$ is limited below the $700 \mathrm{hPa}$ level and the positive temperature anomaly appears above the $500 \mathrm{hPa}$ level. Thus, the vertical structure of respective low temperature areas is different from each other. Note that the thermal structure of LTA-B observed at station M on 19-20 June is different from that of cold air mass accompanied by a deep baloclinic wave.

\subsection{Wind field}

Figure 14a shows the vertical section of wind components around the Plateau at 12UTC 19 June. In this figure, the meridional wind component in the longitudinal section (stations D$\mathrm{M})$ and the zonal wind component in the meridional sections (stations $\mathrm{H}, \mathrm{Q}-\mathrm{T}$ and $\mathrm{M}, \mathrm{U}-\mathrm{X}$ ) are presented. As for the meridional wind component, the contour lines of solid and broken lines indicate southerly and northerly wind, respectively. Concerning the zonal wind, solid
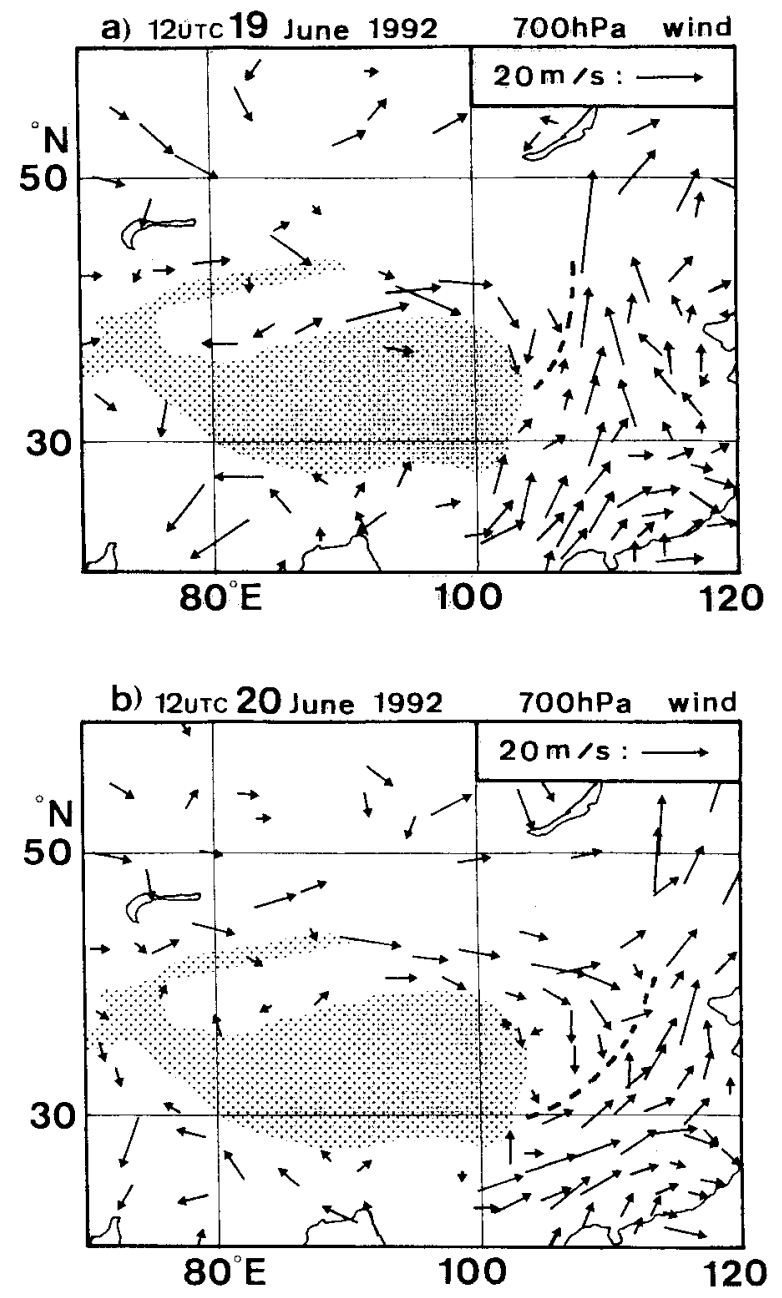

Fig. 15. Distribution of wind vector at the $700 \mathrm{hPa}$ level for 12UTC 19 (a) and 20 (b) June. Location of horizontal wind shear line to the east of the Tibetan Plateau is drawn subjectively (broken line) as the forefront of the westerlynortherly wind.

contour lines and broken ones show westerly and easterly wind, respectively. Furthermore, the vertical sections of wind direction (in eight directions) are presented in Fig. 14b.

According to Fig. 14a, the cores of northerly and southerly wind appear at the $300 \mathrm{hPa}$ level to the west $\left(85-90^{\circ} \mathrm{E}\right)$ and east $\left(95-100^{\circ} \mathrm{E}\right)$ of the LTA-A, respectively. Namely, the LTA-A appears corresponding to the migrating trough in the polar jet stream with polar air mass to the north of it. During this time, the strong westerly wind that reaches the near surface 


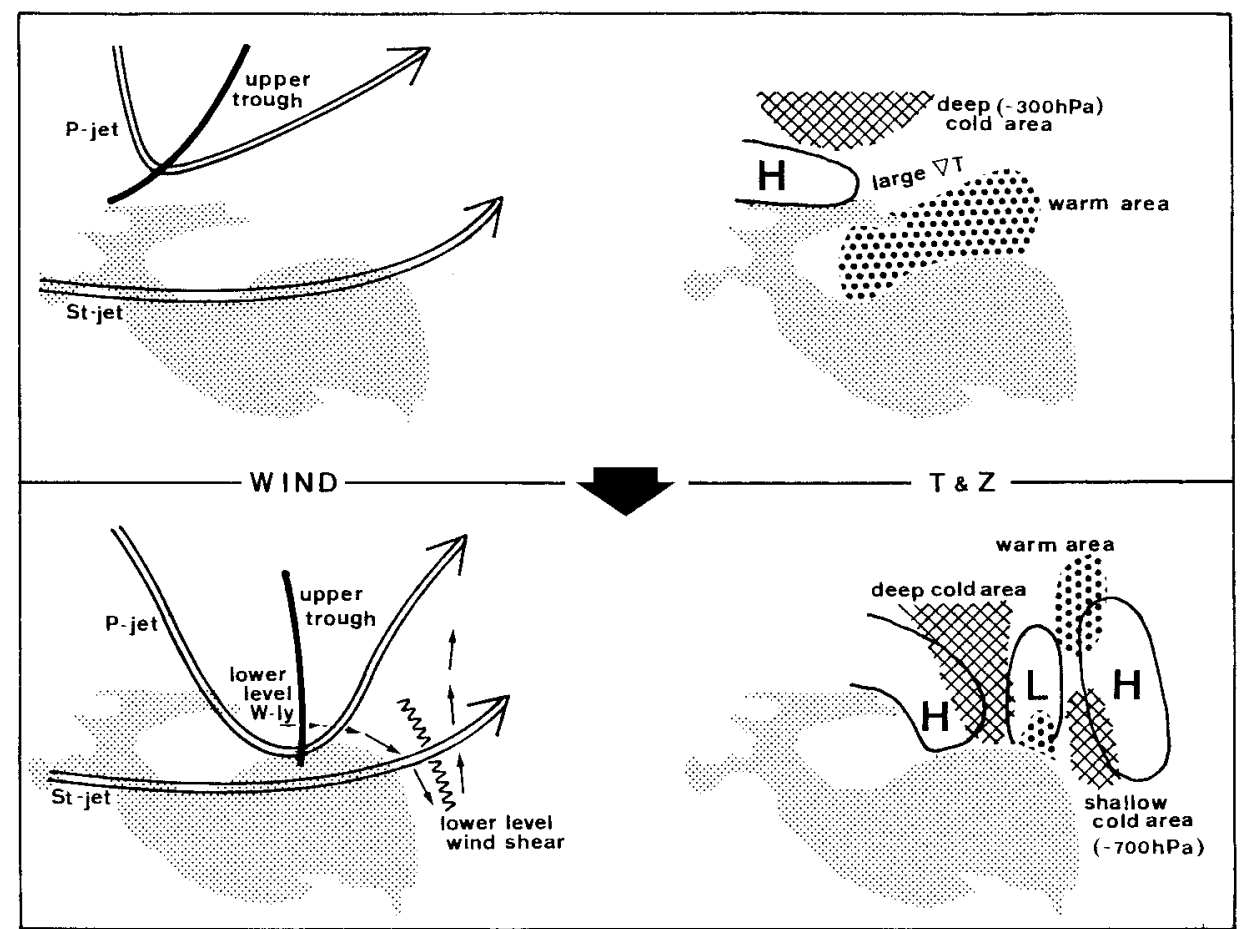

Fig. 16. Schematic illustration showing temporal change in the synoptic field that causes the appearance of the lower level wind shear line (left) and the shallow low temperature area (right) to the east of the Tibetan Plateau. Approximate location of the polar jet stream (P-jet) and the subtropical jet stream (St-jet) is also shown in the figure.

layer appears along the northern periphery $\left(\sim 40^{\circ} \mathrm{N}\right)$ of the Plateau. In addition, the lower level southerly wind blowing from the direction of the Plateau is observed around $95^{\circ} \mathrm{E}$ (Fig. $14 b)$.

On the contrary, to the east of the Plateau, strong westerly wind is not observed around the LTA-B in $105-110^{\circ} \mathrm{E}$ (Fig. 14a). According to Fig. 14b, wind direction below the $500 \mathrm{hPa}$ level varies markedly from northerly or northwesterly to southerly between stations $\mathrm{L}$ and M. Namely, strong horizontal wind shear (cyclonic) is observed in the neighborhood of the LTA-B from the surface to the $500 \mathrm{hPa}$ level. According to the distribution of observed wind vector around the Plateau at the $700 \mathrm{hPa}$ level at 12UTC 19 June (Fig. 15a), the same time as Figs. 13 and 14, a shear line mentioned above is observed as a boundary (broken line) between northerly and southerly winds. The northerly wind originated from the lower level strong westerly wind to the north of the Pla- teau (Fig. 15). Though the orientation of the shear line on 19 June is almost in a north-south direction, it changes to a northeast-southwest direction gradually on 20 June (Fig. 15b) along with the eastward migration of the LTA-B. The shear line on 20 June coincides with the reintensified Mei-yu front that appears in the surface weather chart at 12UTC 20 June (Fig. $3 b)$.

According to Ninomiya and Muraki (1986), the Mei-yu front in the late June of 1979 over China corresponds to the shear line between the northerly wind accompanied by the quasistationary Baiu (Mei-yu) trough and the southerly wind from the South China Sea. However, the northerly or northwesterly wind to the northwest of the shear line in Fig. 15 originated from strong westerly wind along the northern periphery of the Plateau, which appears to be a different wind system than that of the Baiu (Mei-yu) trough. At any rate, the initial shear line can be detected in the eastern 
foot of the Plateau preceding the appearance of the front on the weather chart.

\subsection{Summary of the synoptic field}

Figure 16 summarizes the synoptic-scale process related to the appearance of the cold air mass and the shear line to the east of the Plateau schematically. When the upper level trough approaches the Plateau from the northwest (Fig. 16-upper), the temperature gradient between the deep cold area (LTA-A) accompanied by the westerly trough and the warm area on the northern periphery of the Plateau is enhanced. Simultaneously, the lower level high pressure area with east-west orientation forms to the north of the Plateau.

When the upper level trough with a deep cold area reaches the north of the Plateau (Fig. 16-lower), the low pressure area to the northeast of the Plateau becomes conspicuous, and, thus, the contrast between high and low pressure areas, namely the pressure gradient, is enhanced to the north-northeast of the Plateau. During this time, another cold area (LTAB) emerges between the low pressure area to the northeast of the Plateau and the high pressure area on the North China Plain. Simultaneously, the lower level strong westerly wind appears to the north of the Plateau between LTA-A and around LTA-B. This westerly wind is considered to be an ageostrophic wind system that occurs along the northern periphery of the Plateau, and it turns into a northwesterlynortherly wind along the northern-eastern periphery of the Plateau. Consequently, the shear line in the eastern foot of the Plateau is formed between this northwesterly-northerly wind and the southerly wind over the North-Middle China Plain. After that, this shear line begins to indicate a northeast-southwest orientation gradually in accordance with the eastward migration of the low temperature area, and then the Mei-yu front becomes extinct there.

In the following chapter, the formative process of the shear line in the eastern foot of the Plateau will be discussed further.

\section{Lower level shear line in the eastern foot of the Tibetan Plateau}

\subsection{Evolution of the lower level shear line}

The lower part of Fig. 17 shows the distribution of relative vorticity at the $850 \mathrm{hPa}$ level

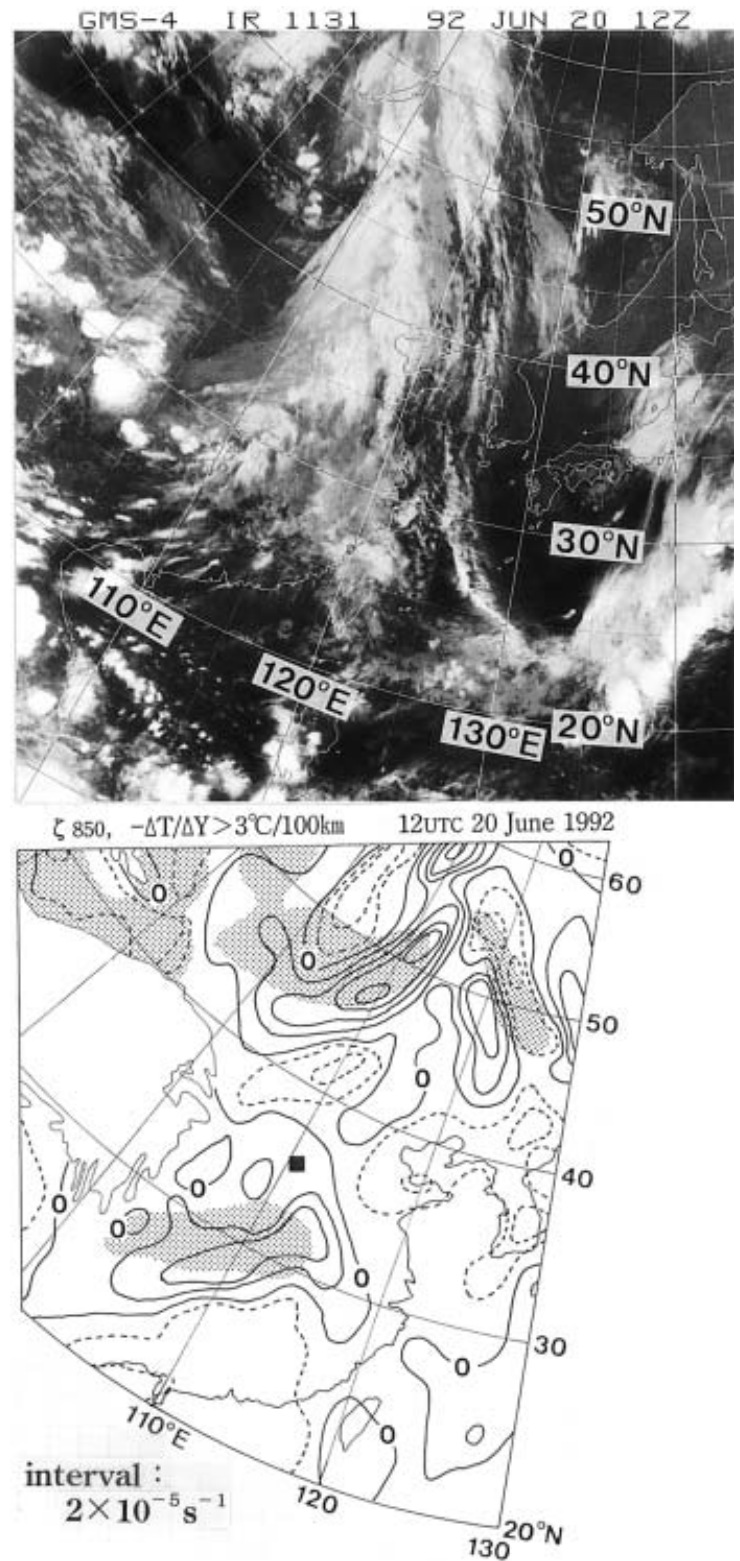

Fig. 17. GMS IR cloud image (upper) and the distribution of relative vorticity at the $850 \mathrm{hPa}$ level (lower) at 12UTC 20 June. Contour lines are drawn at the interval of $2 \times 10^{-5}\left(\mathrm{~s}^{-1}\right)$. Broken contour lines indicate negative value. Shaded areas indicate that $-\Delta \mathrm{T} / \Delta \mathrm{Y}>$ $3^{\circ} \mathrm{C} / 100 \mathrm{~km}$.

calculated by using global objective analysis data (G-ANAL). The area of positive vorticity (solid contour line) to the east of the Plateau is observed corresponding to the Mei-yu front 

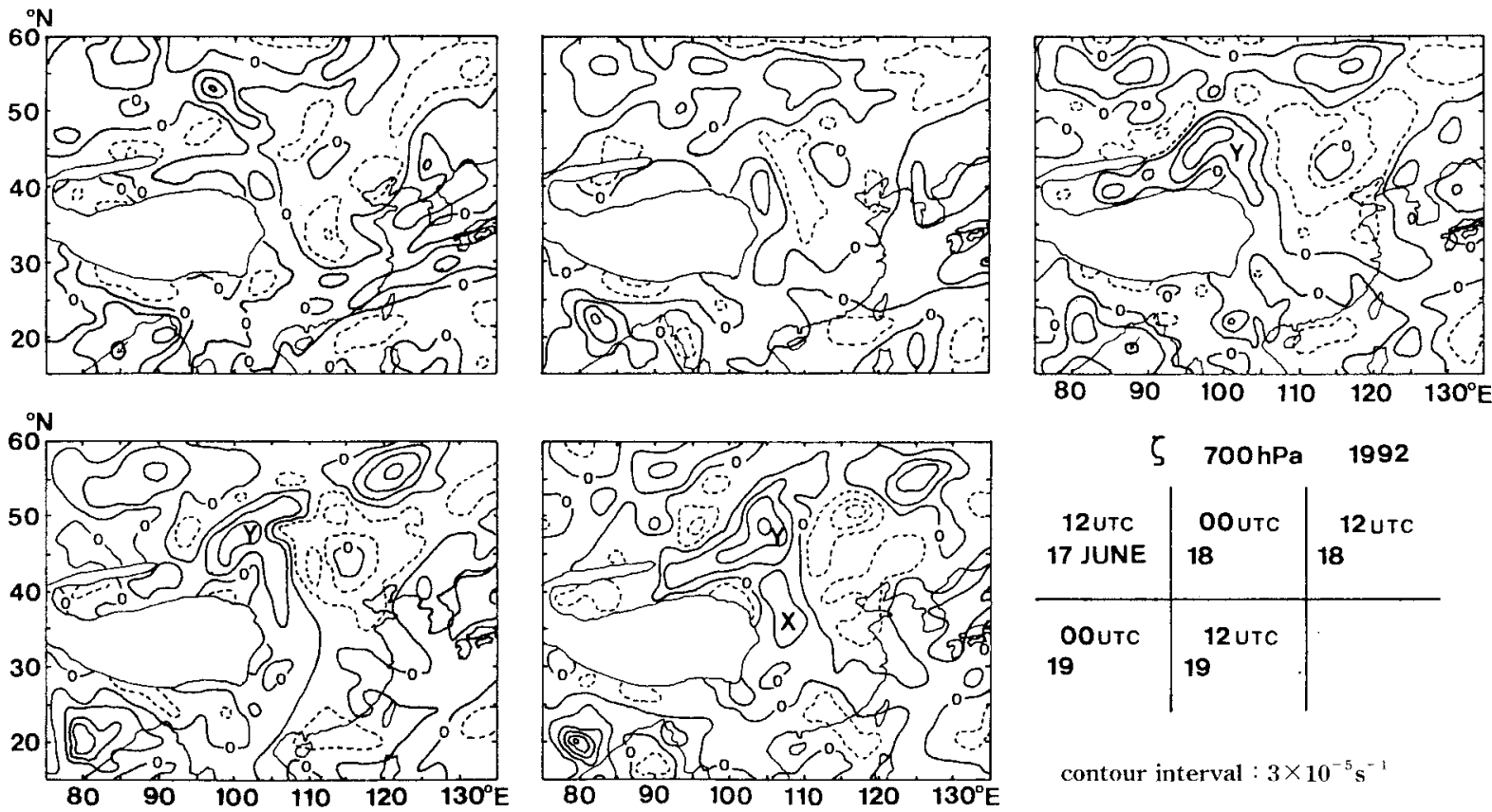

contour interval : $3 \times 10^{-5} \mathrm{~s}^{-1}$
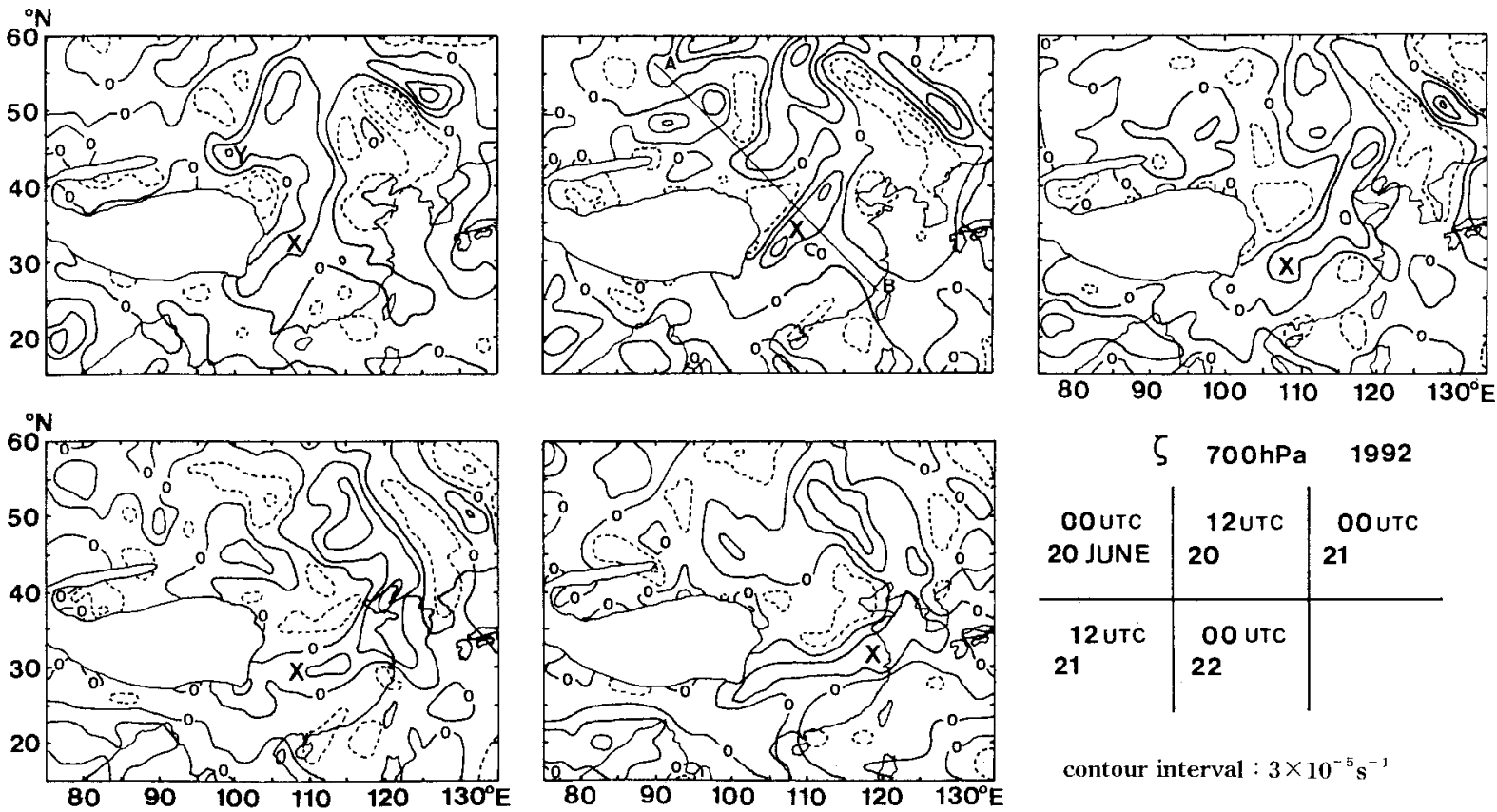

contour interval : $3 \times 10^{-5} \mathrm{~s}^{-1}$

Fig. 18. Day-to-day change in the distribution of relative vorticity at the $700 \mathrm{hPa}$ level (from 12UTC 17 to 00UTC 22 June). Contour lines are drawn at the interval of $3 \times 10^{-5}\left(\mathrm{~s}^{-1}\right)$. Broken contour lines indicate negative value. "X" and "Y" denote the positive vorticity areas referred in the text. 
(Fig. $3 \mathrm{~b}$ ) and the shear line (Fig. 15b) at 12UTC 20 June where convective clouds begin to organize (Fig. 17-upper). Furthermore, the area with a relatively large meridional temperature gradient (shaded area: $\geqq 3^{\circ} \mathrm{C} / 100 \mathrm{~km}$ ) is superimposed on the large positive vorticity area. This localized baroclinic zone is located to the south of the cold air mass (center: $\mathbf{a})$ that appears to the east of the Plateau in Fig. 4.

The zone of positive vorticity to the east of the Plateau can be detected also at the $700 \mathrm{hPa}$ level. To demonstrate the evolution of the shear line in the eastern foot of the Plateau to the Mei-yu front over China, the distribution of relative vorticity at the $700 \mathrm{hPa}$ level every 12 hours is shown in Fig. 18. After 12UTC 20 June, the large positive vorticity area over China $\left(\sim 30^{\circ} \mathrm{N}\right)$ expands from east to west ("X" in Fig. 18). It is prolonged from the southeastern foot of the Plateau to the southern part of Japan Islands at 00UTC 22 June. Before 20 June, the eastern part of the Plateau is surrounded by the positive vorticity area, and the negative vorticity area is located on the northeastern edge of the Plateau. In addition, the positive vorticity area to the north of the Plateau ("Y" in Fig. 18) is marked between 12UTC 18 and 12UTC 19 June. However, the areas of positive and negative vorticity to the north and east of the Plateau are indistinct before 00UTC 18 June.

Considering these facts, it is suspected that the lower level positive vorticity zone with eastwest oriented axis that corresponds to the Meiyu front over China originated from the positive vorticity area (initial shear line) generated in the eastern foot of the Plateau (" $\mathrm{X}$ " in Fig. 18). Furthermore, from the formation of the positive vorticity area to the north of the Plateau ("Y" in Fig. 18), it is expected that some abrupt change in wind field occurs to the northnortheast of the Plateau on 18 June preceding the formation of the initial shear line in the eastern foot of the Plateau.

\subsection{Formation process of the lower level shear line}

In the previous chapter of section 5.2 , it is observed that the initial shear line in the eastern foot of the Plateau appears corresponding to the boundary between the northerly wind originating from the strong westerly wind along the northern-eastern periphery of the Plateau and the southerly wind prevailing over the North-Middle China Plain. In this section, the transient component of height and wind field at the $850 \mathrm{hPa}$ level around the Plateau will be examined. In this analysis, the transient component is defined as an anomaly of daily field from the 10-day average field between 13 and 22 June. Moreover, the transient component of temperature distribution is calculated to detect the relationships among wind, height and temperature fields. The time sequence of day-today change in the transient component of the synoptic field at 12UTC is shown in Fig. 19 that begins at 12UTC 17 June, three days before the target front is detected on the weather chart at 12UTC 20 June. In Fig. 19, contour lines for the height anomaly and the temperature anomaly are drawn at the interval of $20 \mathrm{gpm}$ and $4{ }^{\circ} \mathrm{C}$, respectively. Broken contour lines indicate negative value. As for the anomaly wind, the long barb and short one represent $4 \mathrm{~m} \mathrm{~s}^{-1}$ and $2 \mathrm{~m} \mathrm{~s}^{-1}$, respectively.

At 12UTC 17 June, an area of negative height anomaly (L) is observed to the north of the Plateau. An area of positive height anomaly $(\mathrm{H})$ also is located to the north of the negative height anomaly area mentioned above. In addition, another positive height anomaly area with synoptic-scale is observed over the NorthMiddle China Plain (around $30-40^{\circ} \mathrm{N}$ of 110 $120^{\circ} \mathrm{E}$ ). The latter positive height anomaly area corresponds to the synoptic-scale moving anticyclone that can be detected on the daily weather charts on 17-20 June. During this time, southerly and easterly anomaly winds appear to the east and north of the Plateau, respectively. Directions of these anomaly winds are almost parallel to the contour lines of height anomaly, which implies that the wind system around the Plateau is considered to be a geostrophic wind system. As for the temperature field, the positive anomaly is prevailing to the east of the Plateau, which means that the cold air mass is not emerged there at this time.

At 12UTC 18 June, the positive height anomaly area located in $45-50^{\circ} \mathrm{N}$ to the north of the Plateau on the previous day reaches the northern periphery of the Plateau. According to the GMS IR cloud image at 12UTC 18 June (Fig. 20-upper), the cloudless area on the north of the Plateau $\left(40-45^{\circ} \mathrm{N}\right.$ of $\left.90-95^{\circ} \mathrm{E}\right)$ is observed 

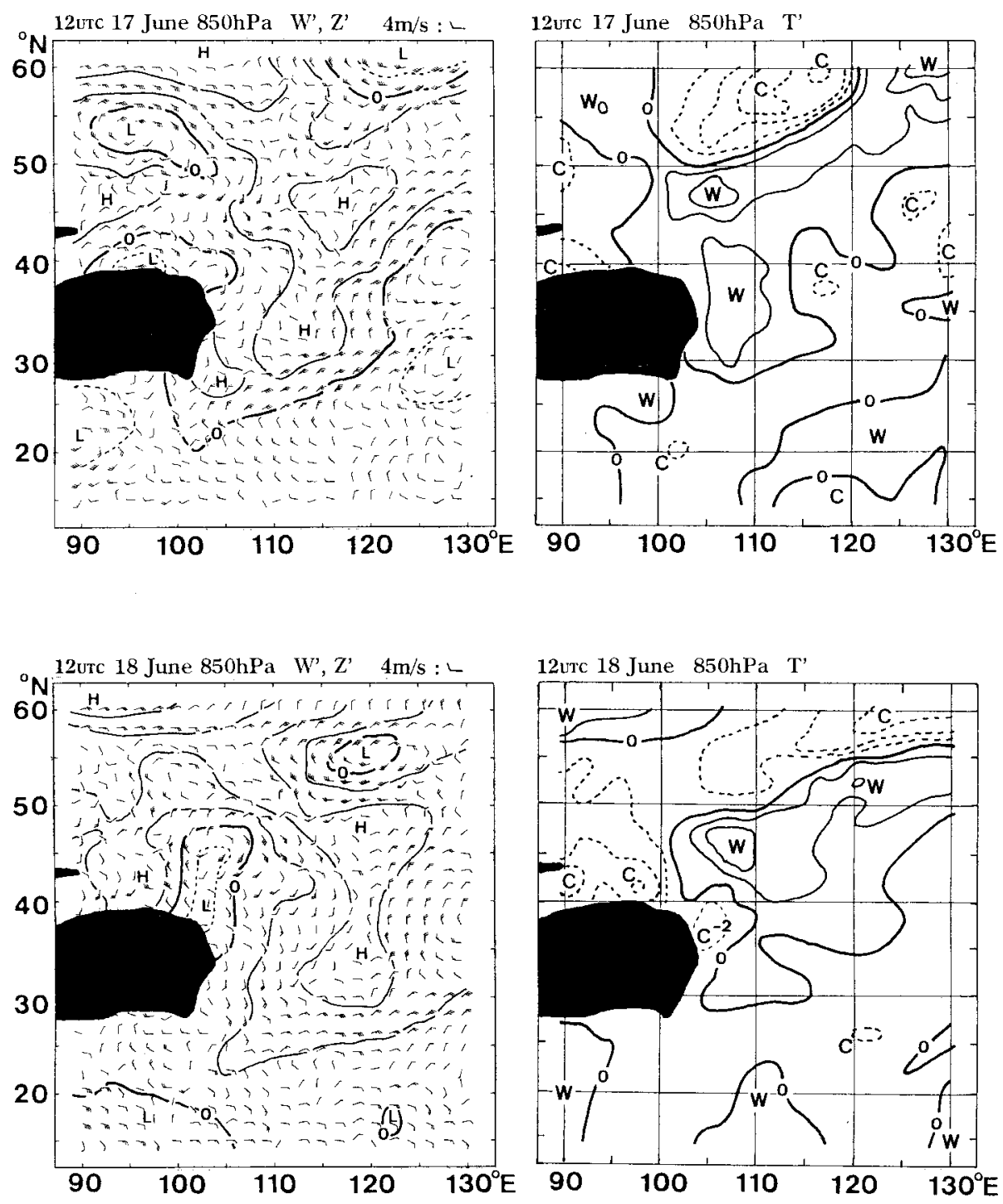

Fig. 19. Day-to-day change in the transient component of wind $\left(\mathrm{W}^{\prime}\right)$, height $\left(\mathrm{Z}^{\prime}\right)$ and temperature $\left(\mathrm{T}^{\prime}\right)$ field around the Tibetan Plateau for 12UTC 17-20 June. Transient component is defined as the anomaly of daily field from the 10-day averaged field (12UTC 13-22 June). Broken contour lines for height $\left(\mathrm{Z}^{\prime}\right)$ and temperature $\left(\mathrm{T}^{\prime}\right)$ indicate negative value.

corresponding to the positive height anomaly area. By contrast, the negative height anomaly area on the northeastern edge of the Plateau becomes conspicuous and shifts eastward slightly. Synchronously, the anomaly wind field around the Plateau has changed markedly compared with 12UTC 17 June. The southerly anomaly wind appears in the positive height anomaly area on the northern periphery of the
Plateau, which is also detected in the observed wind as mentioned in section 5.2 (Fig. 14). This southerly anomaly wind turns westerly, and blows into the negative height anomaly area on the northeastern edge of the Plateau crossing the contour lines of the height anomaly. The maximum velocity of the anomaly wind there exceeds $16 \mathrm{~m} \mathrm{~s}^{-1}$. Therefore, this wind system is considered to be an ageostrophic wind sys- 

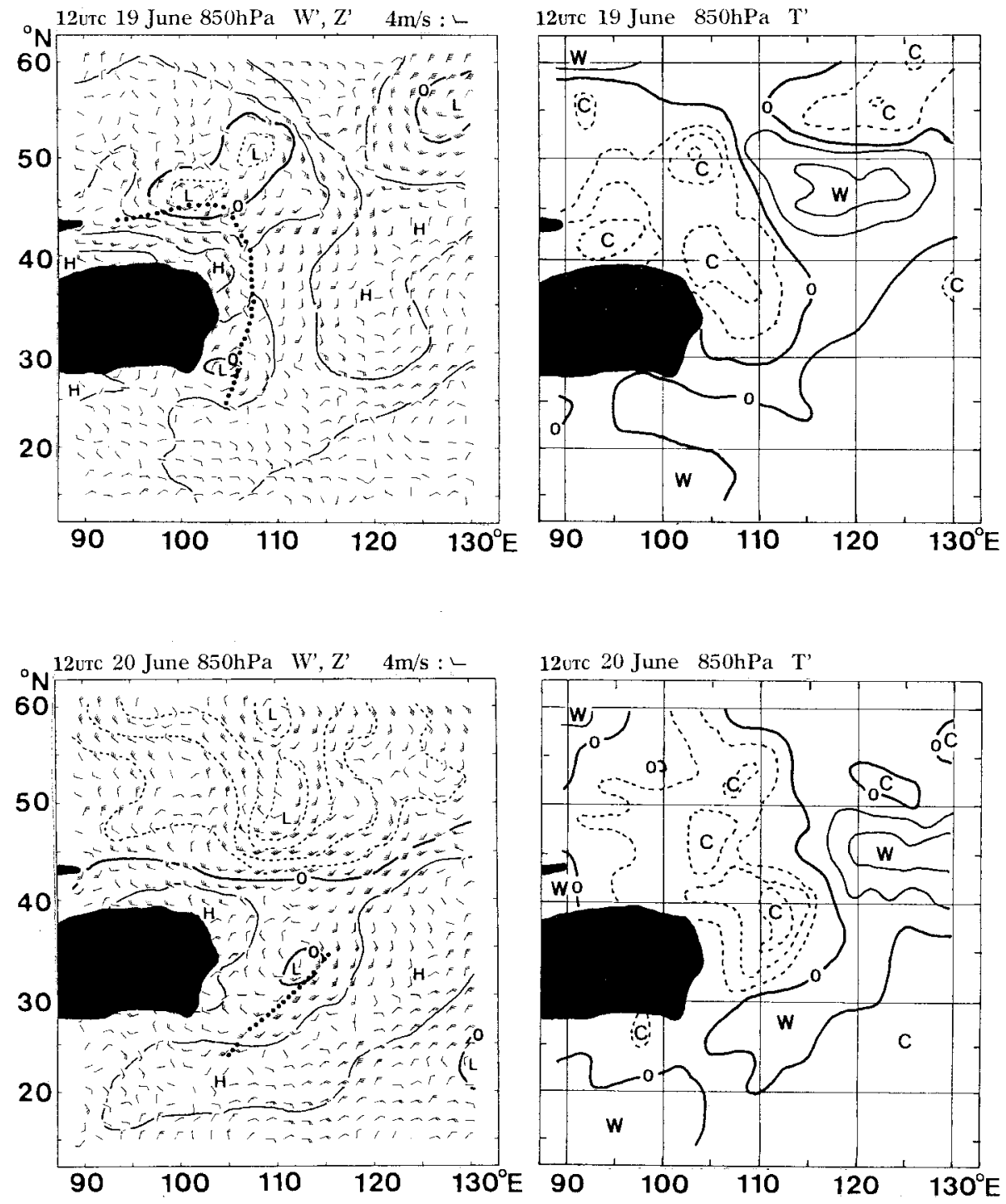

Fig. 19 (continued)

tem; it corresponds to the strong lower level westerly wind to the north of the Plateau observed in the meridional-vertical section (Fig. 14a). Further, the marked positive vorticity area at the $700 \mathrm{hPa}$ level to the north of the Plateau between 12UTC 18 and 12UTC 19 June ("Y" in Fig. 18) corresponds to the northern side of the strong westerly wind axis where the wind velocity decreases northward. At the $850 \mathrm{hPa}$ level (Fig. 20-lower), an area of large positive vorticity, which is not obvious at the $700 \mathrm{hPa}$ level (Fig. 18), is observed to the northeast of the Plateau corresponding to the en- hanced negative height anomaly area and the forefront of the ageostrophic westerly wind. The formation of the initial shear line occurs in the lower layer of the northeastern edge of the Plateau, and is related to the enhancement of the low pressure system there and the appearance of the ageostrophic westerly wind. During this time, a low temperature area $(\mathrm{C})$ can be detected to the southeast of the negative height anomaly area on the northeastern edge of the Plateau.

As for the $850 \mathrm{hPa}$ level vorticity field at 12UTC 19 June (Fig. 21-lower), the positive 

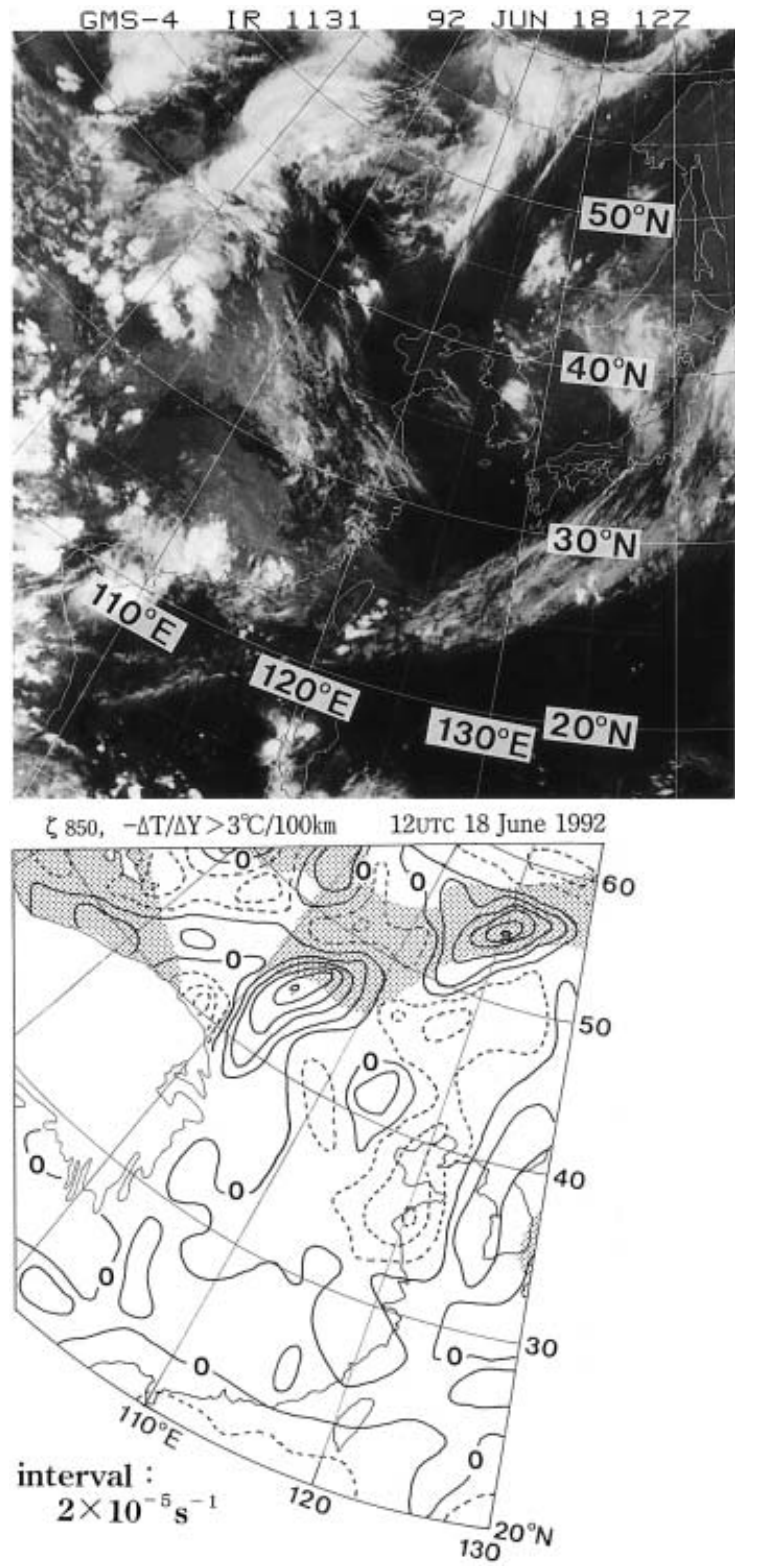

Fig. 20. Same as Fig. 17, but for 12UTC 18 June.

vorticity area located on the northeastern edge of the Plateau on the previous day extends southward, and surrounds the eastern part of the Plateau. The cloudless area $\left(35-45^{\circ} \mathrm{N}\right.$ of $\left.100-110^{\circ} \mathrm{E}\right)$ on the northeast of the Plateau (Fig. 21-upper) also coincides with the negative vorticity area as observed at 12UTC 18 June (Fig. 20-upper). During this time, the positive vorticity zone located to the east of the Plateau
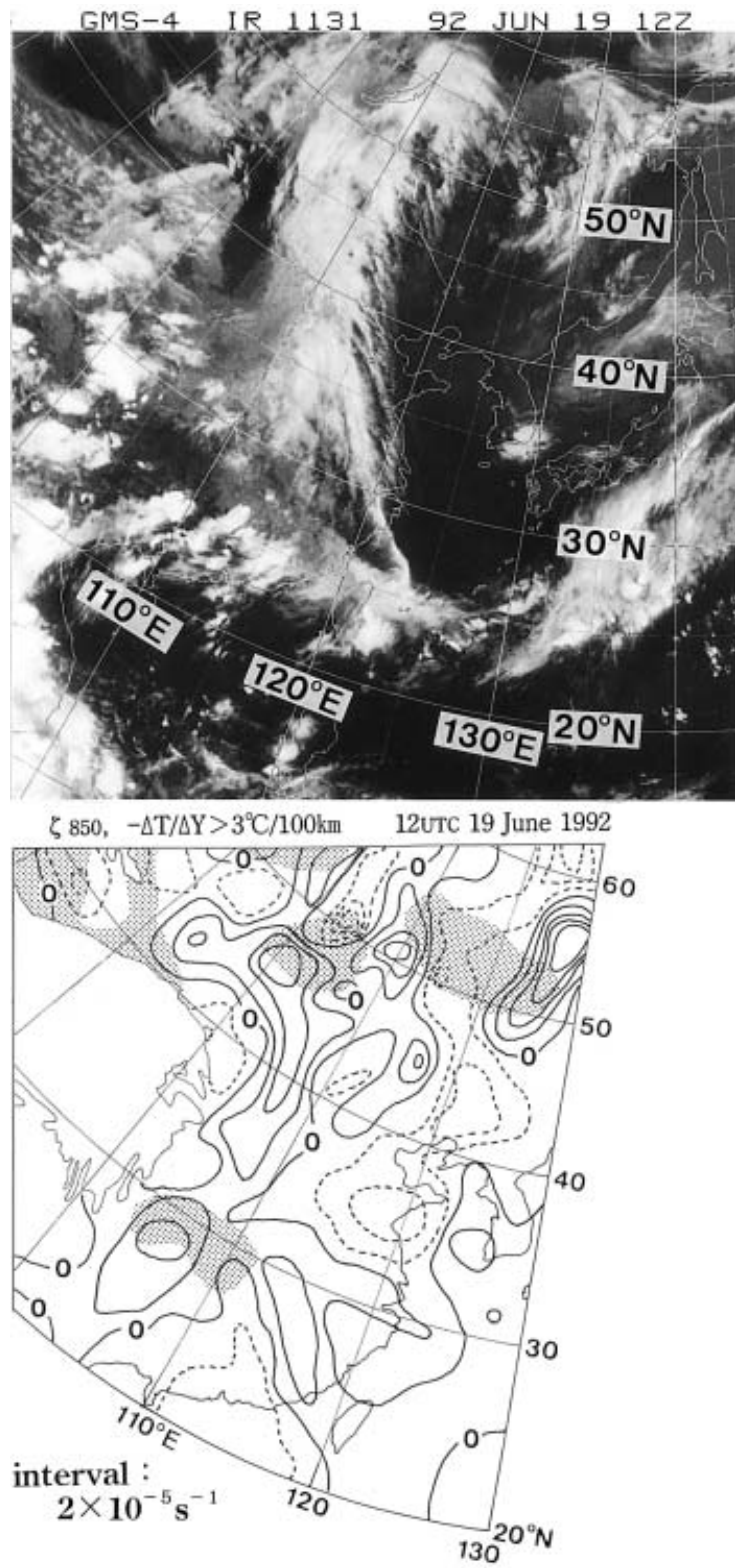

Fig. 21. Same as Fig. 17, but for 12UTC 19 June.

coincides with the western margin of the cloud zone that expands in the north-south direction (Fig. 21-upper). According to Fig. 19, the positive height anomaly area on the northern periphery of the Plateau at 12UTC 18 June seems to be captured by the Plateau at 12UTC 19 June. The positive height anomaly area extends eastward along the northern periphery of the Plateau, and the negative height anom- 
aly, which also is captured by the Plateau, is detected on the southeast of the Plateau at 12UTC 19 June. Concurrently, the anomaly wind of strong ageostrophic northerly direction, which spouts from the positive height anomaly area and blows into the negative height anomaly area, appears along the eastern periphery of the Plateau. To the east of the anomaly northerly wind area, a geostrophic southerly wind anomaly is observed in the western part of the moving high pressure system. The discontinuity of anomaly wind direction between these two wind systems in $105-110^{\circ} \mathrm{E}$ corresponds to the shear line to the eastern foot of the Plateau (dotted line in Fig. 19 for 12UTC 19 June). These facts lead the conclusion that the appearance of the ageostrophic strong northwesterly or northerly wind in the presence of the transient positive and negative height anomaly areas around the Plateau is an essential factor for the formation of the initial shear line to the east of the Plateau. During this time, the area of negative temperature anomaly becomes distinct, and its center is situated almost on this shear line.

A low pressure system called the "southwestvortex" is frequently generated around the southwestern edge of the Plateau. It sometimes causes heavy precipitation in the $\mathrm{Si}$ chuan Basin-Yangtze River basin when the southwest-vortex migrates eastward (Kuo et al. 1986; Wang and Orlanki 1987). The southwestvortex is likely to occur when the upper level trough passes through the Plateau (Ding 1991). It should be interesting to investigate the relationship between the generation of the southwest-vortex and the transient positive and negative height anomaly areas along the periphery of the Plateau as observed in this study.

At 12UTC 20 June in Fig. 19, the positive height anomaly area reaches the southeastern edge of the Plateau, and the ageostrophic wind along the Plateau becomes indistinct. The negative height anomaly area to the south of the negative anomaly area of temperature corresponds to cyclonic anomaly circulation (dotted line in Fig. 19. Refer also to Fig. 18). Although the shear line or positive vorticity zone can pursue temporally, the structure of disturbance may change due to the relatively large temperature gradient and substantial moisture supply from the South China Sea. The deformations of structure of the shear line and the appearance of the cold air mass are further problems to be studied.

\subsection{Coupling with the upper level trough}

The lower level positive vorticity area that appears to the east or north of the Plateau cannot be traced back before 00UTC 18 June (" $\mathrm{X}$ " and "Y" in Fig. 18). By contrast, at the $300 \mathrm{hPa}$ level (Fig. 22), the positive vorticity area located on the northeastern edge of the Plateau at 12UTC 20 June ("Z" in Fig. 22) can be traced back from the west of the Plateau. This upper level positive vorticity area migrates eastward along $40-45^{\circ} \mathrm{N}$ corresponding to the migration of the $500 \mathrm{hPa}$ level trough to the north of the Plateau (Fig. 5). According to the classification of the Mei-yu front structure by Akiyama (1990a), the Mei-yu front that appeared on 20 June is considered to be an active shallow type Mei-yu front, since the center of the upper level positive vorticity locates about $10^{\circ}$ north of the lower level positive vorticity center. Figure 23 shows the vertical cross section of the Mei-yu front (positive vorticity area) to the east of the Plateau (line A-B in Fig. 18 for 12UTC 20 June) for relative vorticity (upper), potential temperature (middle), and equivalent potential temperature (lower) at 12UTC 20 June. In Fig. 23, the frontal surface that tilts northwestward with height can be detected as the maximum gradient zone of potential temperature and equivalent potential temperature. Nevertheless, the centers of positive vorticity exist in the upper and lower level separately corresponding to the upper level trough and lower level shear line, respectively. In addition, it should be noted that the coupling of the upper level migrating trough and the lower level shear line that formed later (e.g., the lower panel of Fig. 16) could be important for further enhancement of the Mei-yu front or a disturbance on it in this case, although their coupling processes will be examined in the future.

\section{Concluding remarks}

Although the climatological Mei-yu frontal zone over China migrates northward gradually during the Mei-yu season, the Mei-yu front on the daily weather charts frequently shows the 

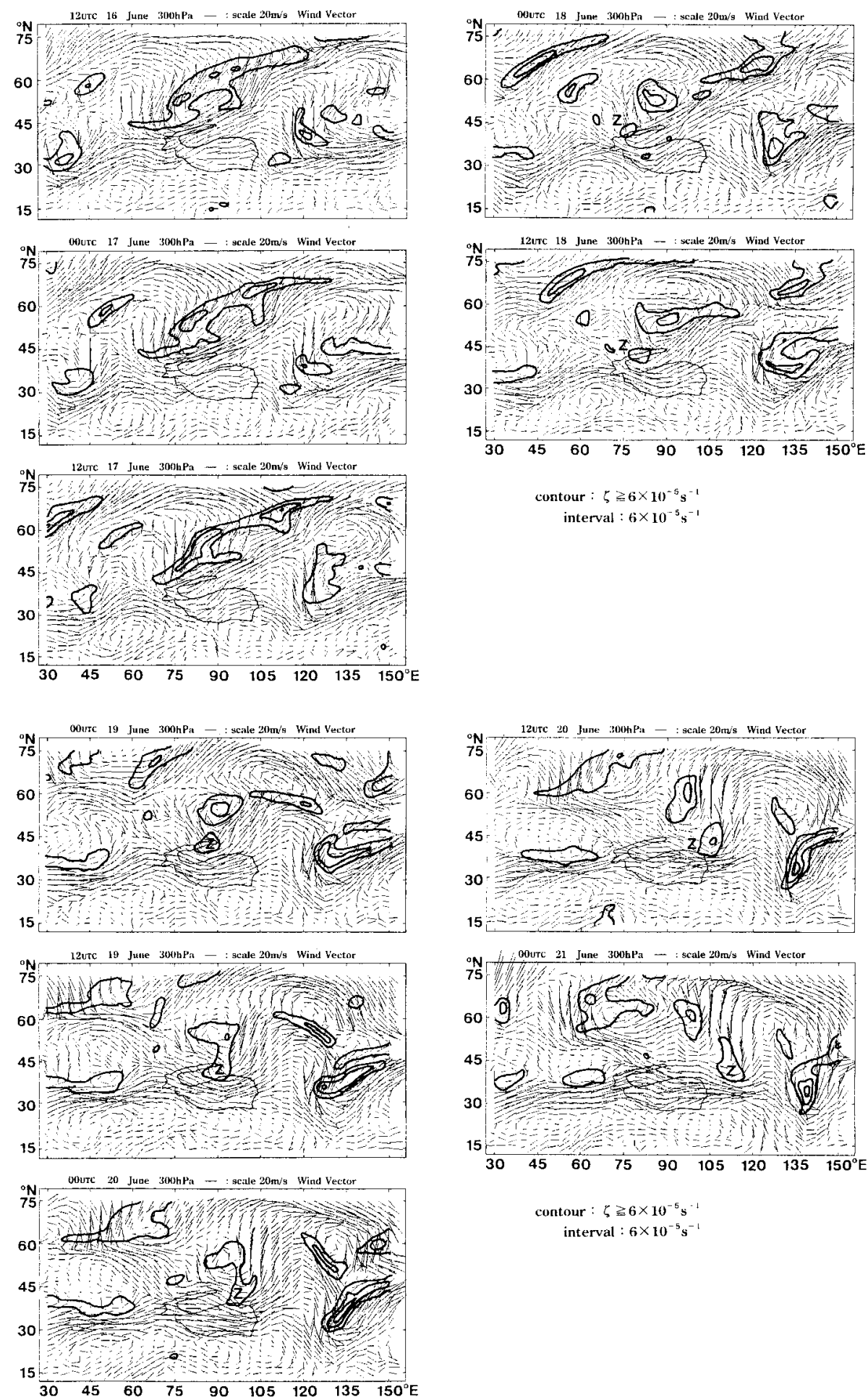

contour: $\zeta \geq 6 \times 10^{-5} \mathrm{~s}$ interval : $6 \times 10^{-5} \mathrm{~s}$

Fig. 22. Day-to-day change in the distribution of wind and relative vorticity at the $300 \mathrm{hPa}$ level from 12UTC 16 to 00UTC 21 June. Contour lines of relative vorticity are drawn only for positive value at the interval of $6 \times 10^{-5}\left(\mathrm{~s}^{-1}\right)$. "Z" denotes the positive vorticity area referred in the text. 

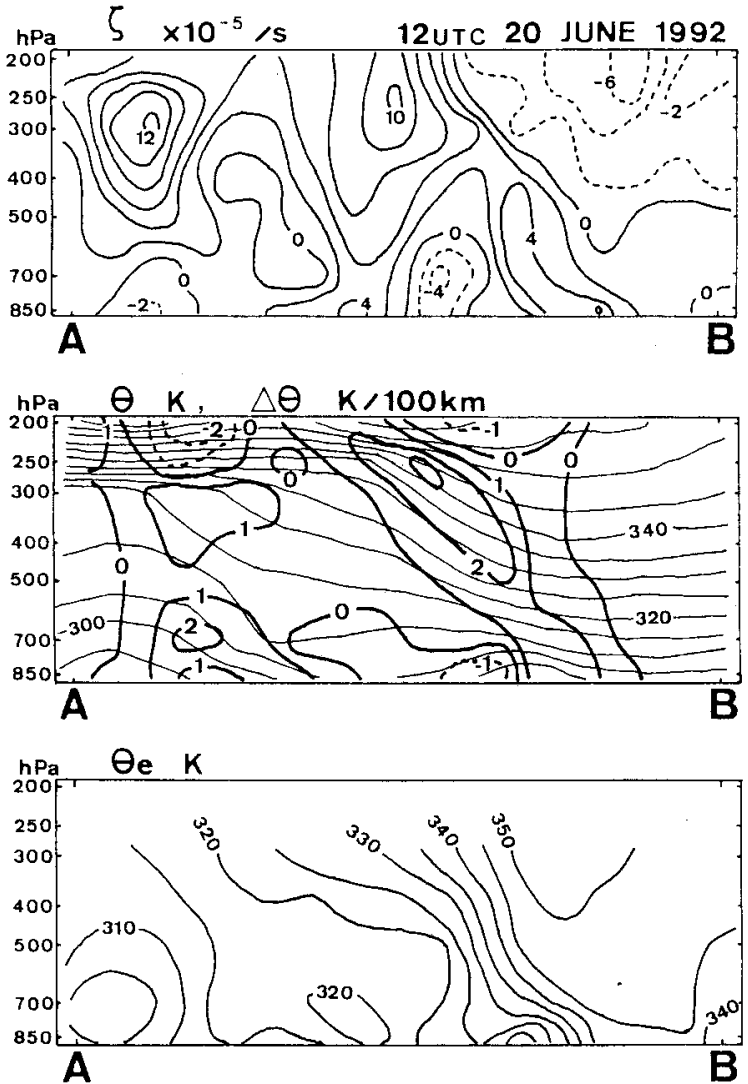

Fig. 23. Vertical section of relative vorticity (upper), potential temperature and its horizontal gradient $(\mathrm{K} / 100 \mathrm{~km})$ (middle), and equivalent potential temperature (lower) across the initial stage Mei-yu front (positive vorticity zone) to the east of the Tibetan Plateau at 12UTC 20 June (along A-B in Fig. 18).

following successive cycles with an appearance around $30^{\circ} \mathrm{N}$ or higher latitude, southward migration, and dissipation around $25^{\circ} \mathrm{N}$ or lower latitude. During the initial stage of such a cycle of the Mei-yu front, a meso- $\alpha$-scale system with a cold air mass often appears in the lower troposphere to the east of the Tibetan Plateau. In this study, to document the initial formation process of the Mei-yu frontal disturbance in the eastern foot of the Plateau, a case study was conducted on the temporal change in the synoptic field around the Plateau. The target period was middle-late June of 1992 during which the re-intensified Mei-yu front was detected on the surface weather chart at 12UTC 20 June.

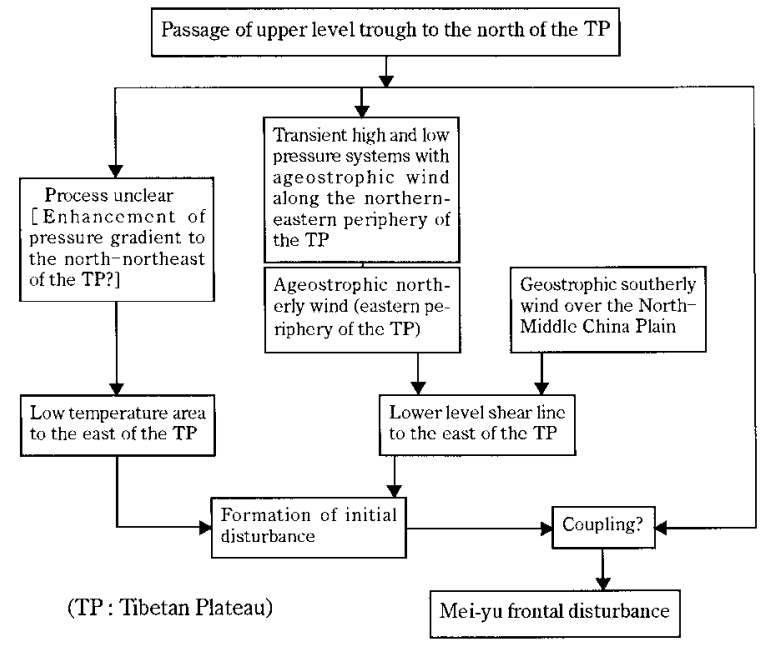

Fig. 24. Summary of the formation process of the Mei-yu frontal disturbance in middle-late June 1992 derived from this study.

The results can be summarized as follows (Fig. 24):

(1) The re-intensification of the Mei-yu front around $30^{\circ} \mathrm{N}$ over China occurred when the eastward migrating upper level trough was situated to the north of the Plateau. As the upper level trough approached the Plateau, a large temperature gradient zone was observed between the deep cold area accompanied by the upper level trough and the warm area on the northern periphery of the Plateau. Simultaneously, a lower level high pressure area with east-west oriented axis appeared to the north of the Plateau. When the upper level trough reached the north of the Plateau, the low pressure area to the northeast of the Plateau in the lower level became conspicuous. The contrast of high and low pressure areas (pressure gradient) in the lower level was enhanced to the north-northeast of the Plateau. During this time, the shallow (below the $700 \mathrm{hPa}$ level) cold air mass emerged between the low pressure area to the northeast of the Plateau and the high pressure area over the North-Middle China Plain. The appearance of the lower level cold air mass might be related to the enhancement of the pressure 
gradient to the north-northeast of the Plateau.

(2) Concurrently, the lower level strong westerly wind appeared along the northern periphery of the Plateau. This westerly wind turned into northwesterly or northerly wind along the eastern periphery of the Plateau. A shear line that results in the Meiyu front was formed in the northeastern or eastern foot of the Plateau between this northwesterly-northerly wind and the southerly winds prevailing over the NorthMiddle China Plain. The wind system along the northern and eastern periphery of the Plateau is considered to be an ageostrophic wind system; it was accompanied by the transient small scale high and low pressure systems that migrated clockwise along the northern-eastern periphery of the Plateau. After that, the shear line gradually indicated east-west orientation in accordance with the eastward migration of the cold air mass in the lower level, and the Mei-yu front became distinct there.

(3) The synchronous appearance of the cold air mass contributing to the uplift of the moist air mass and shear line that caused convergence is considered to be an effective trigger for the formation of the initial Mei-yu frontal disturbance to the east of the Plateau. In addition, the coupling of the upper level disturbance (trough system) and the lower level disturbance (shear line) also should be important for the evolution from shear line to the Mei-yu frontal disturbance.

Though the present analysis treats only one case, it demonstrates that the important atmospheric processes for the formation of the Mei-yu frontal disturbance over China occurs around the Tibetan Plateau. It will be necessary to conduct further analyses about the formation process of the lower level cold air mass to the east of the Plateau and strong ageostrophic wind along the northern-eastern periphery of the Plateau.

\section{Acknowledgments}

The author would like to express his sincere gratitude to Dr. Kuranoshin Kato for his kind suggestions and encouragements, and to two anonymous referees who provided him with many valuable comments. Thanks also are due to Dr. Kiyotoshi Takahashi at the Meteorological Research Institute for providing the SD data. The global objective analysis data was provided by the Japan Meteorological Business Support Center. This research was financially supported by the Grant-in-Aid for Scientific Research, Japanese Ministry of Education, Science, Sports and Culture, No. 07680186.

\section{References}

Akiyama, T., 1973: Ageostrophic low-level jet stream in the Baiu season associated with heavy rainfalls over the sea area. J. Meteor. Soc. Japan, 51, 205-208.

— 1975: Southerly transversal moisture flux into the extremely heavy rainfall zone in the Baiu season. J. Meteor. Soc. Japan, 53, 304316.

Akiyama, T., 1990a: Large, synoptic and meso scale variations of the Baiu front, during July 1982. Part II Frontal structure and disturbances. J. Meteor. Soc. Japan, 68, 557-574.

_ 1990b: Large, synoptic and meso scale variations of the Baiu front, during July 1982. Part III Space-time scale and structure of frontal disturbances. J. Meteor. Soc. Japan, 68, 705727.

Chen, G.T.-J., 1994: Large-scale circulations associated with the East Asian summer monsoon and the Mei-Yu over South China and Taiwan. J. Meteor. Soc. Japan, 72, 959-983.

Ding, Y.-H., 1991: Monsoon over China. Kluwer Academic Publishers, Netherlands, 419p.

, 1992: Summer monsoon rainfalls in China. $J$. Meteor. Soc. Japan, 70, 373-396.

—, Z. Yan, Q. Ma, and G. Hu, 2001: Analysis of the Large-Scale Circulation Features and Synoptic Systems in East Asia During the Intensive Observation Period of GAME/HUBEX. $J$. Meteor. Soc. Japan, 79, 277-300.

Kato, K., 1989: Seasonal transition of the low-level circulation system around the Baiu front in China in 1979 and its relation to the northern summer monsoon. J. Meteor. Soc. Japan, 67, 249-265.

- and T. Kurihara, 1989: Case study on intraseasonal variation of the subtropical high as a moisture transport system and the Baiu cloud distribution (Comparison between the two periods around the middle of June). Tenki, 36, 221-232. (in Japanese)

Kuo, Y.-H., L.S. Cheng, and R.A. Anthes, 1986: Scale analyses of the Sichuan flood catastrophe, 1115 July 1981. Mon. Wea. Rev., 114, 1984-2003. 
Liu, N., 1992: June 1992-Dry in the Huanghuai areas, local heavy rain disasters in the Jiangnan areas. Monthly Meteorological, 18(9), 5861. (in Chinese)

Matsumoto, J., 1985: Precipitation distribution and frontal zones over East Asia in the summer of 1979. Bull. Dept. Geogr., Univ. Tokyo, 17, 4561.

Murakami, T. and W.-G. Huang, 1984: Orographic effects of the Tibetan Plateau on the rainfall variations over central China during the 1979 summer. J. Meteor. Soc. Japan, 62, 895-909.

Ninomiya, K., 1984: Characteristics of Baiu front as a predominant subtropical front in the summer northern hemisphere. J. Meteor. Soc. Japan, 62, 880-894.

- and H. Muraki, 1986: Large-scale circulations over East Asia during Baiu period of 1979. J. Meteor. Soc. Japan, 64, 409-429.

and T. Akiyama, 1992: Multi-scale features of Baiu, the summer monsoon over Japan and the East Asia. J. Meteor. Soc. Japan, 70, 467495.

Takahashi, H., 1989: Formation of a rain belt and the structure of the front during the Baiu season on the Chinese continent. Geogr. Rev. Ja- pan, 62A, 853-876. (in Japanese with English abstract)

1991: Migration of a cold air mass related to rain belt formation on the Chinese continent and atmospheric circulation systems during the Baiu season. Geogr. Rev. Japan, 64A, 697718. (in Japanese with English abstract)

Tang, H., 1992: July 1992-Waterlogging followed by dryness in the south, rain after a drier spell in the north. Meteorological Monthly, 18(10), 58-61. (in Chinese)

Wang B. and I. Orlanski, 1987: Study of a heavy rain vortex formed over the eastern flank of the Tibetan Plateau. Mon. Wea. Rev., 115, 13701393.

Yoshimura, M., 1967: Annual change in frontal zone in the northern hemisphere. Geogr. Rev. Japan, 40, 393-408. (in Japanese with English abstract)

Yoshino, M.M., 1963: Rainfall, frontal zones and jet stream in early summer over East Asia. Bonner Meteorologische Abhandlungen, 3, 1-127.

, 1969: Climatological studies of the polar frontal zones and the intertropical convergence zones over South, Southeast and East Asia. Climatological Note Hosei Univ., 1, 1-71. 